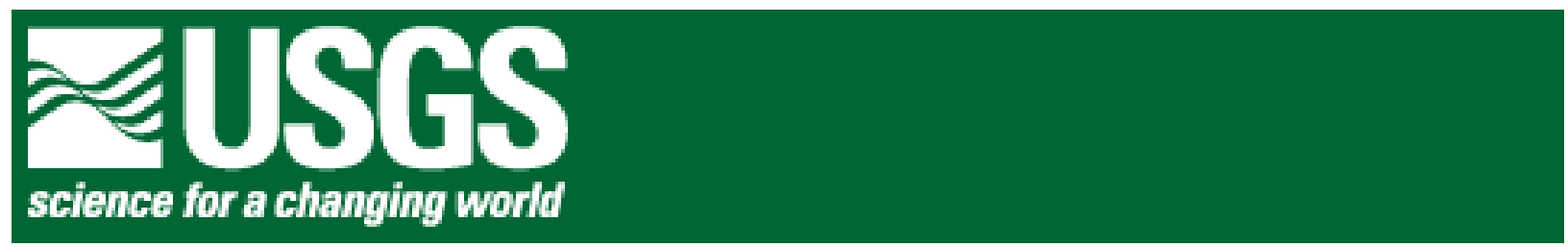

\title{
HOLOCENE FAULT SCARPS AND SHALLOW MAGNETIC ANOMALIES ALONG THE SOUTHERN WHIDBEY ISLAND FAULT ZONE NEAR WOODINVILLE, WASHINGTON
}

By Brian L. Sherrod, Richard J. Blakely, Craig Weaver, Harvey Kelsey, Elizabeth Barnett, and Ray Wells

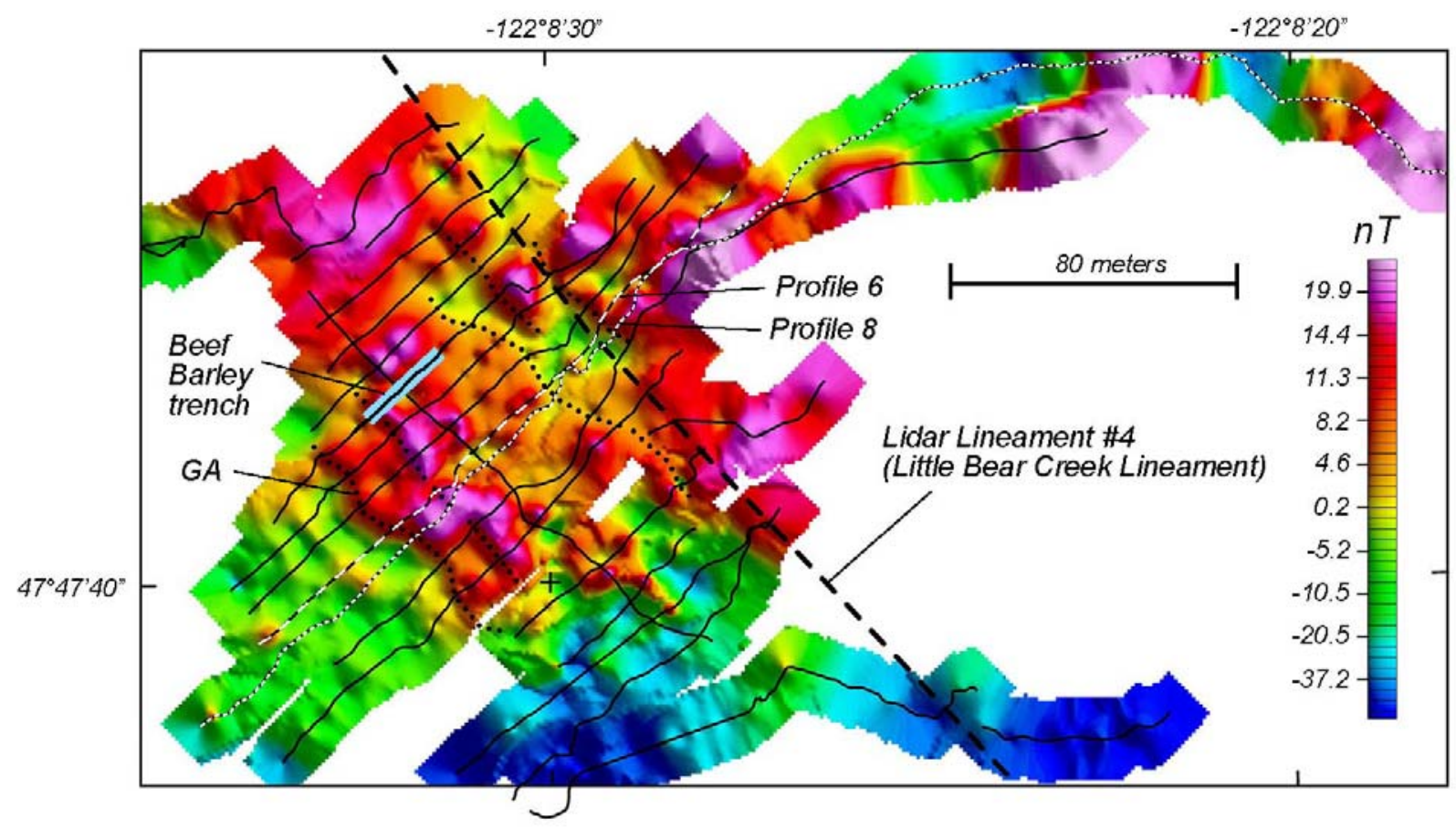

Open-File Report 2005-1136

March 2005

U.S. Department of the Interior

U.S. Geological Survey 


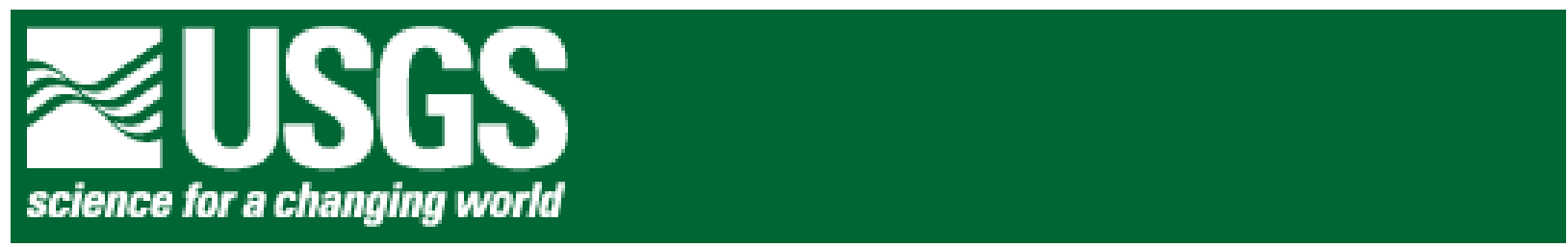

\title{
HOLOCENE FAULT SCARPS AND SHALLOW
}

MAGNETIC ANOMALIES ALONG THE SOUTHERN

WHIDBEY ISLAND FAULT ZONE NEAR

WOODINVILLE, WASHINGTON

\author{
By Brian L. Sherrod', Richard J. Blakely², Craig Weaver', Harvey Kelsey ${ }^{3}$ Elizabeth Barnett', and Ray Wells ${ }^{4}$ \\ ${ }^{1}$ U.S. Geological Survey, Dept. of Earth and Space Sciences, Box 351310, Univ. Washington, Seattle, WA 98195 \\ ${ }^{2}$ U.S. Geological Survey, 345 Middlefield Road, M/S 989, Menlo Park, CA 94025 \\ ${ }^{3}$ Dept. of Geology, Humboldt State University, Arcata, CA 95521 \\ ${ }^{4}$ U.S. Geological Survey, 345 Middlefield Road, M/S 973, Menlo Park, CA 94025
}

Open-File Report 2005-1136

March 2005

This report is preliminary and has not been reviewed for conformity with U.S Geological Survey editorial standards nor with the North American Stratigraphic Code. Any use of trade, product, or firm names in this publication is for descriptive purposes only and does not imply endorsement by the U.S. Government.

U.S. Department of the Interior

U.S. Geological Survey 


\section{ABSTRACT}

The southern Whidbey Island fault zone (SWIFZ), as previously mapped using borehole data, potential-field anomalies, and marine seismic-reflection surveys, consists of four subparallel, northwest-trending fault strands, extending $100 \mathrm{~km}$ from near Vancouver Island to the Washington mainland. The vertical component of displacement changes both across and along the fault, and strike slip motion may be important as well. Abrupt uplift at a coastal marsh on south-central Whidbey Island suggests that the SWIFZ experienced a $\mathrm{M}_{\mathrm{W}} 6.5$ - 7.0 earthquake between 3200 and 2800 years B.P. The SWIFZ has been hypothesized to extend southeastward beneath the mainland, making landfall between the cities of Seattle and Everett. Linear, lowamplitude aeromagnetic anomalies in this mainland region are on strike with the SWIFZ and may facilitate mapping the SWIFZ onshore. The most prominent of the residual aeromagnetic anomalies, the Cottage Lake aeromagnetic lineament, extends at least $16 \mathrm{~km}$, lies approximately on strike with the SWIFZ on Whidbey Island, and passes within about $27 \mathrm{~km}$ of downtown Everett. Glacial deposits are slightly magnetic in this region, as indicated by magnetic susceptibility measurements and a ground-magnetic survey, and, in places, the Cottage Lake aeromagnetic lineament is associated with topographic lineaments. Spectral analysis and modeling experiments indicate that the source of the Cottage Lake aeromagnetic lineament extends to depths greater than $2 \mathrm{~km}$ and into Eocene sedimentary strata.

Subtle scarps on Pleistocene surfaces are visible on high-resolution lidar topography at a number of locations in the mainland region, often closely associated with aeromagnetic lineaments. In the field, scarps exhibit northeast-side-up vertical relief of 1 to $5 \mathrm{~m}$. One group of scarps extends a total distance of $18 \mathrm{~km}$ along the Cottage Lake aeromagnetic lineament, where they defines two strands: One strand lies east of Crystal Lake and is referred to here as the Crystal Lake lidar lineament, another strand follows the Little Bear Creek drainage and is called here the Little Bear Creek lidar lineament. Four excavations across these two lidar lineaments show evidence for multiple folding and faulting events since deglaciation, most likely above buried reverse/oblique faults. One trench exposed a normal fault, although it was not possible to determine whether slip was caused by glacial or tectonic processes. In this same trench, evidence for younger folding suggests that surface deformation during an earthquake formed the scarp seen on lidar maps near Crystal Lake. Subsequent scarp degradation buried a forest soil, from which charcoal samples indicated that the folding event occurred after 11,670 years B.P. Two trenches were also excavated along the Little Bear Creak lineament near Grace, Washington. One of these trenches showed evidence for multiple events, including both folding and faulting, with the youngest event disturbing late Holocene wetland soils. In total, paleoseismological evidence suggests that the SWIFZ produced at four events since deglaciation about 16,400 years ago, the most recent after $2.7 \mathrm{ka}$. Liquefaction features near Everett indicate that strong shaking has occurred there at least three times in the last 1100 years, although evidence that those earthquakes occurred on the SWIFZ has not yet been found.

\section{INTRODUCTION}

The southern Whidbey Island fault zone is imaged by a variety of geophysical methods as a broad, complex, northwest-striking structure extending from southern Whidbey Island to Vancouver Island (Figures 1 and 2). The SWIFZ appears in gravity and seismic tomography inversions as a structural contact between low-velocity, low-density sediments of the Everett basin and high-velocity, high-density Crescent Formation that underlies the Kingston arch 
(Brocher and others, 2001; Gower and others, 1985; Johnson and others, 1996; Ramachandran and others, 2005). The SWIFZ was originally mapped on the basis of regional gravity and magnetic anomalies as a single strand extending northwest from about Murphys Corner on the Washington mainland to Admiralty Inlet west of Whidbey Island (Gower and others, 1985; Yount and Gower, 1991). Johnson and others (1996) showed evidence in seismic-reflection data, exposures in sea cliffs, and nearby boreholes for Quaternary displacement on three separate strands of the SWIFZ and extended the zone northwestward nearly to Vancouver Island. Kelsey and others (2004) interpreted differences in relative sea-level histories at two coastal marshes on opposite sides of one strand of the SWIFZ as evidence for 1-2 m of vertical, north-side-up displacement during a $\mathrm{M}_{\mathrm{W}} 6.5$ to 7.0 earthquake about 3000 years ago.

While other shallow faults in the Puget Lowland show distinct aeromagnetic patterns associated with hanging-wall geology (Blakely and others, 2002), the aeromagnetic expression of the SWIFZ is broad, complex, and diffuse, possibly because strongly magnetic lithologies, like the Crescent Formation, lie at significant depths. The SWIFZ is expressed in aeromagnetic anomalies across Admiralty Inlet, but the southeastward extension of the SWIFZ from southern Whidbey Island onto the Washington mainland is subdued in unprocessed aeromagnetic data. Aeromagnetic anomalies do display a subtle northwest-striking pattern of magnetic lineaments in the Maltby-Woodinville area, particularly evident after application of data enhancement methodologies (Blakely and others, 2004). This pattern is on strike with the SWIFZ offshore and is spatially associated with a narrow, 18-km-long zone of topographic scarps and lineaments identified in a GIS analysis of lidar data. The scarps are typically 1 to $5 \mathrm{~m}$ high, have northeastside up, and lie on Pleistocene and younger surfaces. On the basis of their spatial association with topographic scarps and lineaments, we earlier interpreted some of the northwest-striking aeromagnetic lineaments as onshore splays of the SWIFZ, thereby extending the zone of past deformation approximately $30 \mathrm{~km}$ beyond the mainland coast (Blakely and others, 2004).

A detailed description of the aeromagnetic survey and evidence for onshore extension of the SWIFZ were provided by Blakely and others (2004). In their report, Blakely and others (2004) used a numbering scheme to designate lidar features. In particular, they referred to lineament 4 as a set of topographic features that follows the Little Bear Creek drainage and crosses the site of a proposed sewage treatment facility in southern Snohomish County, and they referred to features 10 and 11 as two scarps east of Crystal Lake. In this report, we designate lineament 4 as the Little Bear Creek lineament and the scarps east of Crystal Lake as the Crystal Lake lineament. Both of these topographic features lie along the larger Cottage Lake aeromagnetic lineament. In the following section, we summarize the results of Blakely and others (2004) and their implications for more recent paleoseismic field investigations.

\section{AEROMAGNETIC ANOMALIES}

In 1997 the U.S. Geological Survey conducted a high-resolution aeromagnetic survey of the Puget Sound and adjacent areas (Blakely and others, 1999). Flight altitude was targeted at $250 \mathrm{~m}$ above ground or as low as permitted by safety considerations; over the MaltbyWoodinville area, flight altitude was nominally $262 \mathrm{~m}$ above terrain. North-directed flight lines were spaced $400 \mathrm{~m}$ apart over the Puget Lowland; east-directed tie lines were spaced at $8 \mathrm{~km}$ intervals. Two base magnetometers operated continuously during the survey in order to subsequently correct for time-varying fields. Subtraction of the International Geomagnetic Reference Field provided total-field aeromagnetic anomalies. Taking all sources of error into account, we estimate the overall precision of individual measurements to be $0.5 \mathrm{nT}$ or better 
(Blakely and others, 2004). [nT is an abbreviation for nanotesla, a unit of measure for magnetic flux density, or the "strength" of the magnetic field.. $1 \mathrm{nT}=10^{-9}$ Tesla. See Blakely (1995) for additional information.]

Figure 3A shows unprocessed aeromagnetic anomalies over the study area. Most anomalies in Figure 3A, especially those of regional extent, are caused by variations in magnetization of subsurface lithologies, and the evidence for and implications of these anomalies are discussed below. A "dimpled" pattern is also evident in some parts of Figure 3A, especially along the mainland coast. This short-wavelength pattern originates from large buildings and other manmade structures. For example, the anomaly southeast of Mukilteo (label C, Figure 3A) is situated over a Boeing facility and probably is caused by associated buildings and other infrastructure.

Magnetic anomalies and possible source lithologies

The onshore portion of the study area is dominated by two broad, high-amplitude anomalies (anomalies A and B, Figure 3A). Anomaly A south of Snohomish extends over Bald Hill and Devils Butte, which are underlain by Tertiary volcanic rocks of Mount Persis (Johnson and others, 1996; Minard, 1985; Tabor and others, 1993; Yount and Gower, 1991). These locally exposed Tertiary volcanic rocks probably extend in the subsurface throughout the region beneath anomaly A.

A second broad, high-amplitude magnetic anomaly (anomaly B, Figure 3A) is situated over the Maltby-Woodinville area. The high amplitude of anomaly B requires highly magnetic rocks, and its broad gradients indicate that the source lies at depths of several kilometers.

Potential sources include Tertiary volcanic rocks of Mount Persis and basaltic rocks of the Eocene Crescent Formation.

A subtle pattern of aeromagnetic anomalies is superimposed on anomaly B and adjacent areas. The pattern is characterized by northwest-striking lineaments, each extending more or less continuously for distances of 2 to $16 \mathrm{~km}$. The narrow gradient across each lineament indicates that they originate from the shallow subsurface, and we can highlight their expression by computationally emphasizing anomalies caused by shallow sources in Figure 3A. Figure 3B shows one such method, known as "residual magnetic anomalies". Residual anomalies are calculated by transforming observed anomalies into those anomalies that would be observed at a slightly higher elevation (50 $\mathrm{m}$ higher in this case), a process known as upward continuation, then subtracting that result from the observed anomalies (Blakely and others, 2004).

The northwest-striking pattern of residual magnetic anomalies appears throughout the onshore portion of the study area but is best represented in the Maltby-Woodinville area. The pattern is bounded to the northeast by a pronounced northwest-striking lineament (lineament E, Figure 3B) that also forms the northeastern margin of anomaly B. South of magnetic lineament $\mathrm{E}$, the lineaments each separate positive regions to the northeast from less positive regions to the southwest. The lineaments are not associated with manmade structures and must be caused by subsurface lithologies. The longest and most pronounced of these lineaments (lineament D, Figure 3B), referred to as the Cottage Lake aeromagnetic lineament in Blakely and others (2004), is spatially associated with scarps identified in lidar terrain mapping. Without exception, the sense of offset on these topographic scarps when observed in the field is northeast-side-up. Similarly, the sense of each magnetic gradient (northeast-side more positive than the southwest side) is consistent with northeast-side-up offset on a normally magnetized body. Blakely and others (2004) concluded that lineament D (the Cottage Lake aeromagnetic lineament) and other linear aeromagnetic anomalies in the Maltby-Woodinville area are caused by strands of the 


\section{SWIFZ.}

The lithologic source of the magnetic lineaments is of considerable interest. The sharp gradients of the lineaments indicate that they originate in part from relatively shallow depths, within the upper 1 to $2 \mathrm{~km}$, and thus linear magnetic sources extend structurally higher than the source of anomaly B. Two nearby exploratory wells provide insights into possible magnetic lithologies at these depths. The Standard Oil Company of California Alderwood \#1 well (label SA, Figure 3A) encountered unconsolidated Pleistocene glacial and interglacial deposits to a depth of $110 \mathrm{~m}$; penetrated mudstone, siltstone, and sandstone of the upper Eocene to lower Oligocene Blakeley Formation to a depth of $1591 \mathrm{~m}$; and bottomed in sedimentary and volcanic rocks interpreted by Rau and Johnson (1999) as Eocene sandstone of Scow Bay. The Standard Oil Company of California Socal-Schroeder \#1 well (label SS, Figure 3A) passed through 207 m of unconsolidated Pleistocene glacial and interglacial deposits; penetrated Blakeley Formation and Renton Formation to a depth of 2438 m; then encountered Tertiary volcanic rocks interpreted by Rau and Johnson (1999) as volcanic rocks of Mount Persis. The volcanic-derived lithologies encountered near the bottom of each of these wells are clearly potential sources for the aeromagnetic lineaments, if those lithologies lie at shallow enough depths. Magnetic susceptibility measurements in the Maltby-Snohomish area (Blakely and others, 2004) found that even Pleistocene glacial deposits and coarse-grained units within the Blakeley Formation are sometimes weakly magnetic.

\section{GROUND-MAGNETIC SURVEY}

An open field traversed by the Little Bear Creek lidar lineament (lineament 4 on Fig. 4) afforded an excellent opportunity to conduct a ground-magnetic survey in a region of linear aeromagnetic anomalies. The motivation for this investigation was to help determine the lithologic source of aeromagnetic lineaments throughout the Maltby-Woodinville area. The open field was also the site of the "Beef Barley" trench excavation (Fig. 4), discussed subsequently, and the ground-magnetic survey provided an opportunity to characterize surrounding and underlying lithologies. The open field was ideal for this type of investigation: First, it contained no significant metallic objects (buildings, metal fences, pipes, culverts, etc.) to contaminate the magnetic field. A small amount of wire was uncovered during the trench excavation (see following), but its volume was too small to significantly affect the magnetic measurements. Second, the lack of tree cover facilitated accurate GPS determinations.

\section{Survey Specifications}

The survey was conducted prior to the Beef Barley trench excavation. Profiles were conducted on foot while carrying a Geometrics 858 magnetometer system. The 858 system includes a cesium-vapor magnetic sensor, real-time GPS navigational equipment, and a small breast-pack computer. Seventeen profiles were directed northeast and spaced nominally $9 \mathrm{~m}$ apart; a single profile was directed northwestward through the future trench site. Measurements were made at 1 -second intervals while walking at a normal pace. According to the manufacturer, the Geometrics 858 magnetometer has a sensitivity of $0.01 \mathrm{nT}$ when operated at 1.0 -second intervals. A stationary base station was established within the open field and operated simultaneously with the ground-magnetic survey in order to subsequently correct for diurnal variations of the earth's magnetic field and external field fluctuations. The base-station sensor was a Geometrics 856 proton-precession magnetometer. According to the manufacturer, this magnetometer has a resolution of $0.1 \mathrm{nT}$ and an accuracy of $0.5 \mathrm{nT}$. 


\section{Ground Magnetic Anomalies}

Figure 4 shows the ground-magnetic survey. Magnetic field values measured along each profile were corrected for time-varying magnetic fields as recorded at the base station, and then interpolated to a projected rectangular grid using a standard minimum-curvature algorithm. No other processing was applied to the data shown in Figure 4. Individual anomalies typically range between -40 and $+20 \mathrm{nT}$ and have gradient widths on the order of a few tens of meters. Individual anomalies measured at ground level with these characteristics would not appear at aeromagnetic altitudes (262 m).

The ground-magnetic anomalies are small in amplitude, considering that they were measured $2 \mathrm{~m}$ above ground, but we are struck by the linear nature of the anomalies and their dominantly northwest-strike parallel to the Little Bear Creek topographic lineament (lidar lineament 4 of Blakely and others (2004)) and on strike with the SWIFZ. Several pronounced northwest-striking lineaments are evident, shown by the hand-drawn dotted lines on Figure 4; one passes through the Beef Barley trench site, three lie near lidar lineament 4 (Blakely and others, 2004), and a fifth (ground-magnetic lineament GA, Figure 4) lies southwest of the trench. The trench could not be extended to this southwestern-most lineament because of environmental restrictions.

\section{Depth and lithology of likely sources}

The sharp gradients of these linear anomalies indicate that their sources lie at shallow depth. To confirm that assertion, we applied a graphical approach to estimate the depth to the magnetic sources of ground-magnetic lineament GA (Figure 4) beneath profiles 6 and 8. The technique, known as "Peters' method” (Blakely, 1995; Peters, 1949), is based on an important property of magnetic anomalies: The horizontal gradient at the margins of a magnetic anomaly depends on the depth to source; i.e., a shallow magnetic body produces a sharper magnetic anomaly relative to an anomaly caused by the same body at deeper depth. Peters' method is graphical in nature: Draw two parallel lines (dotted lines in Figure 5) with slope equal to one half of the maximum gradient of the anomaly (dashed lines in Figure 5), one line tangent to the peak of the anomaly and the other line tangent to the minimum part of the anomaly. The horizontal separation of the two lines is proportional to the depth to the top of the body. The proportionality constant is 1.2 for very thin bodies and 2.0 for very thick bodies. We chose a value of 1.2, assuming that glacial strata are relatively thin in this region. Peters' method assumes that the magnetic anomaly is caused by a two-dimensional body with vertical sides and uniform and nearly vertical magnetization. Although the magnetic sources under investigation here are two-dimensional in nature, the other underlying assumptions are less likely to be realized. Therefore, our estimates should be treated as only approximate.

Based on Peters' method, we estimate that the top of the magnetic source of lineament GA lies in the upper 8 to $20 \mathrm{~m}$ (Figure 5). Geo-technical boreholes indicate that Pleistocene glacial deposits extend to depths of about $100 \mathrm{~m}$ in this area (AspectConsulting, 2005). Thus, Pleistocene glacial deposits are apparently the lithologic source of the linear anomalies seen in ground-magnetic profiles. In the area of the Beef Barley trench specifically, boreholes encountered glacial till, overlain by outwash, at depths increasing west-southwestward across the trench site (Aspect Consulting, 2005). Extrapolating from these boreholes, we estimate the glacial till to lie approximately $10 \mathrm{~m}$ below ground level at ground-magnetic anomaly GA, roughly equivalent to the magnetic source depth $(8.6 \mathrm{~m})$ estimated from Peter's method. Several explanations for the ground-magnetic anomalies are possible. (1) The anomalies may originate from lateral variations in magnetic properties caused by contrasting depositional 
processes within the Pleistocene section, such as contacts between outwash and channel deposits. (2) The anomalies may be caused by concentrations of secondary magnetic minerals, possibly related to persistent elevated ground-water levels. (3) The anomalies may be caused by faulted offsets of Pleistocene strata. We favor the third interpretation because of the linear nature of the anomalies and their orientation relative to the Little Bear Creek lidar lineament, linear aeromagnetic anomalies, and the onshore extension of the SWIFZ.

Magnetic susceptibility measurements of deposits exposed in the trench wall ranged from $0.62 \times 10^{-3}$ to $10.30 \times 10^{-3} \mathrm{SIU}$, with an average of $2.25 \times 10^{-3} \mathrm{SIU}$. [SIU is an abbreviation for Système Internationale unit. Magnetic susceptibility is proportional to induced magnetization; it is a dimensionless quantity, but its numerical value depends on the units of measure. See Blakely (1995) for additional information.] This average susceptibility would produce an induced magnetization of about $0.10 \mathrm{~A} / \mathrm{m}$. [A/m, or ampere per meter, is the unit of magnetization. See Blakely (1995) for additional information.] Susceptibility measurements of glacial till recovered from geo-technical boreholes in the area had similar magnetic susceptibilities (average 2.75x10-3 SIU).

The range of magnetic susceptibilities observed in the Beef Barley trench is marginally sufficient to explain the ground-magnetic anomalies. We verified this assertion with a simple forward model (Blakely, 1995): a horizontal layer with magnetic susceptibility of $7 \times 10^{-3} \mathrm{SIU}$ relative to overlying strata, a value near the high end of the measured range, and with a northwest-striking, 5-m vertical offset of its upper surface located directly beneath groundmagnetic anomaly GA. If the depth to the layer is $13 \mathrm{~m}$ on the southwest side of the vertical offset and $8 \mathrm{~m}$ on the northeast side, the calculated anomaly has approximately the same amplitude and wavelength as observed in ground-magnetic anomaly GA.

Relationship between ground-magnetic and aeromagnetic anomalies

We suggest that the linear anomalies in Figure 4 are caused by linear offsets in magnetic glacial deposits in the upper 8 to $20 \mathrm{~m}$. It is important to recognize, however, that glacial deposits alone cannot also account for the aeromagnetic lineaments. Individual ground-level anomalies with characteristics described here would not be detectable at aeromagnetic altitudes (approximately $262 \mathrm{~m}$ ), yet the ground-magnetic anomalies do lie near and parallel to the Little

Bear Creak aeromagnetic lineament (Figure 3B). As suggested by Blakely and others (2004), the aeromagnetic anomalies may be caused by faults that intersect both the Pleistocene section and deeper, more magnetic lithologies.

\section{PALEOSEISMOLOGY OF THE SWIFZ}

Geophysical studies of the SWIFZ suggest that several offshore splays project onto the mainland between Edmonds and Mukilteo (Figure 6). Lidar images reveal several post-glacial scarps that sit astride magnetic anomalies and topographic lineaments. Although scarps may be formed by a variety of surficial processes, the correlation of scarps with deeper geophysical structure suggests that the scarps may be related to faulting on strands of the SWIFZ. To test this hypothesis, we excavated trenches across scarps at four sites to look for earthquake-related deformation of surficial deposits. The potential for recent earthquakes in this area is also suggested by evidence for a recent earthquake along the SWIFZ on Whidbey Island (Kelsey and others, 2004).

Summary of Whidbey Island paleoseismology

Relative sea level (RSL) histories at two coastal marshes straddling the SWIFZ on Whidbey Island show evidence for abrupt uplift between 3200 and 2800 cal yr B.P. (Figures 2 
and 7). Sea level curves for Crockett and Hancock marshes, developed using radiocarbon ages from sand/peat contacts beneath each marsh, should be nearly identical if the sites experienced no past deformation. However, combined RSL curves show that the Crockett marsh curve is displaced about 2 m relative to the Hancock marsh curve (Figure 7). Kelsey et al. (2004) inferred that an earthquake caused the changes they observed in the RSL histories from the two marshes. The earthquake, caused by reverse offset on a fault tip concealed beneath a fold on central Whidbey Island, occurred between 3200 and 2800 cal yr B.P. (Kelsey and others, 2004). The fold and fault, imaged on high-resolution seismic reflection profiles in Admiralty Inlet and Holmes Harbor, lies hidden beneath a mantle of deformed late Quaternary glacial deposits. The seismic data show an asymmetrical syncline, with a steeper limb on the north side, developed in Quaternary glacial deposits. Kelsey et al. (2004) inferred that the syncline is cut by a steep reverse fault, possibly dipping $60^{\circ}$.

Prehistoric liquefaction at the Snohomish River delta

Bourgeois and Johnson (2001) found evidence for several events at the Snohomish River delta near Everett, Washington. Outcrops along tidal channels, exposed at low tide, revealed evidence for several episodes of strong shaking. This evidence consists mainly of upward terminating sand dikes and sand-filled cracks, some up to 1 meter wide. The dikes and cracks cut layers containing organic materials usable for radiocarbon dating. The radiocarbon ages and stratigraphic relationships show that strong shaking events occurred 1205-1025 years B.P., 10951015 years B.P., and 575-365 years B.P. Because the evidence for these events consists of liquefaction features, Bourgeois and Johnson (2001) could not attribute the strong shaking to a specific source. Shaking may have been caused by a Cascadia subduction zone earthquake, intraslab earthquake, or shallow earthquake in the Puget Lowland.

Evidence for past surface rupture from lidar and historical aerial photographs

Lidar mapping and historical aerial photographs of northern King County and southern Snohomish County reveal several features along the mainland trace of the SWIFZ (Figures 6, 8 and 9). The extent of lidar coverage from King County is shown on Figure 6 and only covers part of the area traversed by the mainland projection of the SWIFZ. Poor quality and artifacts in the King County lidar data limited the resolution of our lidar analysis (Blakely and others, 2004). We identified several lidar scarps in the area near Crystal Lake and Cottage Lake (Figure 9). These features consist mainly of short $(<1 \mathrm{~km})$, north-side-up scarps and longer topographic lineaments ( 0.5 - 4 km long). No lidar data exists for most of Snohomish County. Therefore, we relied on historical aerial photographs to search for features possibly related to past surface rupture in southern Snohomish County. Features mapped from historical aerial photographs near Devil's Butte in Snohomish County (Figure 8) appear on both the 1933 and 1938 Army Corps of Engineers photographs (Collins and others, 2005). These features consist of short scarps and longer topographic lineaments paralleling the Snohomish River near Devil's Butte.

The lidar and aerial photograph features fall close to, or directly on, previously identified low-amplitude magnetic anomalies (Figure 6). Some of these anomalies are thought to represent strands of the SWIFZ in the shallow subsurface. The largest and most continuous aeromagnetic anomaly is the Cottage Lake aeromagnetic lineament. Two topographic lineaments that lie on top of and southwest of the larger Cottage Lake aeromagnetic lineament - the 'Crystal Lake lineament' and the 'Little Bear Creek lineament' - were selected for field study in the summer of 2004. To test the hypothesis that the topographic lineaments coincided with active faults, we mapped excavations placed across scarps at four sites. 


\section{SELECTION OF STUDY SITES AND FIELD METHODS}

Between June and October, 2004, the USGS opened and mapped four excavations across scarps lying along the onshore extension of the SWIFZ. The excavation sites lay along discrete topographic lineaments, found using lidar maps, within the larger Cottage Lake aeromagnetic lineament. Specifically, two of the excavations cross scarps along a 3-km-long topographic feature known as the Little Bear Creek lineament, and two lie along a 3-km-long scarp near Crystal Lake (Figures 6 and 9). The excavations were placed perpendicular to the scarps to depths between 1.2 and $2.4 \mathrm{~m}$. Excavation walls higher than $1.2 \mathrm{~m}$ were sloped at about 1:1 for safety. After establishing a 1-m by 1-m grid system in each excavation, field teams flagged stratigraphic contacts and structural features using colored surveyor's tape and nails, and mapped selected excavation walls on rectified digital photomosaics.

\section{EXCAVATIONS ACROSS THE CRYSTAL LAKE LINEAMENT}

A north-side-up scarp lying along the Cottage Lake aeromagnetic lineament is the most prominent scarp observed in the lidar data (Figure 9). The scarp, previously identified as Feature 10 and Lineament 11 in Blakely et al. (2004) and herein called the Crystal Lake lineament, is about $3 \mathrm{~km}$ long, and is sub-parallel to the eastern shoreline of Crystal Lake. Profiles across the scarp using the lidar data show a broad, north-side-up scarp between 2.5 and $4 \mathrm{~m}$ in height. Field observations confirm the scarp location and approximate height. The scarp is not clear on the lidar map at its southeast end due to poor lidar returns in dense vegetation.

Two sites along the Crystal Lake lineament were selected for excavation on the basis of lidar data and field reconnaissance (Figure 9). The two excavation sites, named Mountain Beaver and Flying Squirrel, lie 100 to 200 m east of Crystal Lake in a mature Douglas-fir forest. Mountain Beaver site

The Mountain Beaver site consists of a 16-m long excavation with sloping walls (about a 1:1 slope). This excavation exposed deposits from the last glacial advance into the Puget Lowland (Figure 10). This glacial advance, regionally called Vashon, culminated around 16,400 cal yr B.P. when the glacier disintegrated, leaving behind outwash deposits and glacial drift (Porter and Swanson, 1998). Glacial drift exposed in the excavation consisted of dense gray sandy silt with faceted pebbles and cobbles (Qvt). Overlying the drift is a thin layer of dense silt that is laminated in places (Qste). The silt is in turn overlain by a pebbly drift consisting of dense sandy silt with abundant faceted pebbles and cobbles, and discontinuous stratified sand layers $(\mathrm{Qd})$.

A fault separates the pebbly drift (Qd) from overlying sand and pebbly silty sands (Qrs) that contain large intact blocks of Qd (Figure 10 and 11). The fault truncates and deforms sand and silt layers in the pebbly drift (Qd) such that a normal sense of movement on the fault is clearly observed. Photographs of the fault show truncated and deformed beds, and show a shear fabric parallel to the fault (Figure 11). Overlying the fault is a sequence of massive to interbedded sand and pebbly silty sands that pinch out towards the middle of the trench wall (Qrs). A clast of charcoal from a silty fine sand layer (sample MB001 from Qrs) yielded an AMS radiocarbon age of 31,330 \pm 340 C14 yr B.P. Overlying Qrs is a buried A-horizon (Hab). A charcoal clast collected from the stratigraphic middle of Hab in the west wall (not shown in Figure 10) of the excavation yielded an AMS radiocarbon age of 10,190 \pm 40 C14 yr B.P. (12,090 - 11,670 cal yr B.P.). Gravel lenses (not shown in Figure 10) and a silty colluvial deposit (Hc and Hcs) bury the former A-horizon and underlying deposits. The loose character of unit Hc 
makes it an ideal habitat for mountain beaver (Aplodontia ruppia). Several filled and open Aplodontia burrows were noted during field work, and several live Aplodontia were observed in the excavations. The tops of the excavation walls are mantled with surface accumulations of modern forest litter (Ha), with thicker accumulations near the base of the scarp.

Flying Squirrel site

The Flying Squirrel site is a 20-m long excavation across a 3.5-m high, north-side-up scarp (Figure 12). Eight lithologic units mapped in the excavation provide a stratigraphic section spanning from the Vashon advance to the present. Vashon till is exposed at the base of the stratigraphic section and consists of a gray sandy loam with faceted pebbles and cobbles of mainly felsic and intermediate rocks (unit Qvt on Figure 12). An erosional unconformity separates the till from overlying Vashon recessional outwash deposits.

The Vashon recessional outwash deposits consist of four mappable units. The oldest unit is a gray, gravelly, fine to coarse sand to sandy gravel (Qrg). Interbedded with unit Qrg are two similar units - a gray, pebbly, fine to coarse sand with crossbedding (Qrgs), and a gray, fine to coarse, crossbedded sand (Qrs). A thin silt layer with laminations (Qste) caps the recessional outwash deposits. Unit Qste is assumed to be a good indicator of paleohorizontal; however, dips of Qste range from an average of about $10^{\circ}$ to almost $40^{\circ}$ below the foot of the scarp (between 6 and $10 \mathrm{~m})$.

Unit Qste is overlain by a gray, pebbly sandy loam (unit Qd) with planar and cross stratification observed in several places. A thick, reddish-brown sandy loam to loam, with weak sub-blocky pedogenic structures and scattered pebbles and cobbles (Hc) overlies the entire section. Tree roots and burrows of Aplodontia ruppia extend downward from ground surface into Hc. Former burrows and filled cavities from rotted tree roots occur in several unmapped sections of the excavation. A thin layer of organic detritus (unit Ha) overlies unit Hc and mantles the ground surface.

\section{EXCAVATIONS ACROSS THE LITTLE BEAR CREEK LINEAMENT}

The Little Bear Creek lineament follows the Little Bear Creek drainage and lies parallel to and along an aeromagnetic anomaly about $1.5 \mathrm{~km}$ southwest of the Cottage Lake aeromagnetic lineament (Figures 6 and 9). The southeastern part of the lineament is aligned along a deep ravine and several scarps. To investigate whether the lineament is a strand of an active fault, we selected two sites with degraded scarps for further study based on field reconnaissance. Detailed logs of the sites, named French Onion and Beef Barley after the pervasive aroma of soups produced in a nearby facility, are shown in Sherrod and others (2005). French Onion site

The French Onion site is an excavation across a small scarp on the south side of a narrow ridge (Figure 13). The ridge is oriented northeast-southwest and bordered on the southeast and northwest by deep ravines eroded into late Quaternary glacial deposits. A small scarp lying along the Little Bear Creek lineament crosses the southwest end of the ridge. A shallow excavation across the scarp revealed eight stratigraphic units composed of glacial lake deposits, till, and Holocene soils.

The oldest units found in the French Onion excavation are glacial lake deposits, presumably of Late Pleistocene age (Figure 13). A brown to gray, laminated claystone (Qscl) and a brown mudstone (Qmud) lie at the base of the exposed section. Overlying Qscl is a massive to laminated, gray claystone (Qmcl). A small lens of glacial drift, probably a till (Qt), is located between 12 and $15 \mathrm{~m}$ and is nearly surrounded by Qmud. All of these units were slightly 
indurated, possibly as a result of overconsolidation below the bed of a thick glacier. No materials for radiometric dating were observed in the glacial deposits, but the overconsolidation is consistent with these units being deposits from an earlier glacial advance that were subsequently overridden by glacial ice during the Vashon advance.

Overlying the glacial deposits in the French Onion trench is a series of Holocene soils and colluvial deposits. A thick layer of buried organic-rich sandy loam to loam lies directly on the Qmud unit (unit Hab between 6 and $9 \mathrm{~m}$ on Figure 13). Immediately overlying Hab are two colluvial units - Hcol and Hpcol on Figure 11. Hcol is a brown sandy loam to loam and contains scattered charcoal clasts. Hpcol is similar to Hcol but has abundant pebble-sized clasts of mudstone. The mudstone pebbles were likely derived upslope from weathering of units Qscl, Qmud, and Qmcl. Hpcol overlies Hcol between 4 and 6 meters on Figure 11. A dark brown organic detritus layer (Ha) caps the stratigraphic section.

Beef Barley site

The Beef Barley site consists of an excavation 30 meters long and 2.4 meters deep, oriented $\mathrm{N} 55^{\circ} \mathrm{E}$ (Figures 14 and 15). Approximately the upper meter of exposed soil consisted of fill containing shards of colored glass, a small amount of fence wire, and machine-cut lumber. The soils below the fill appeared undisturbed and likely span the time interval from Vashon recessional outwash to development of the Little Bear Creek drainage and historic settlement.

The oldest stratigraphic units found in the Beef Barley excavation were two discrete sequences of recessional outwash deposits (Figure 14). Neither sequence is overconsolidated, indicating that neither was overridden by glacial ice. The lack of overconsolidation suggests that the sequences are Vashon recessional outwash deposits. The first sequence (sequence Q1; units Q1a to Q1g on Figure 14) consists of yellowish brown to olive brown pebbly sand, loamy sand, and sandy loam. Locally, gravel beds within sequence Q1 dip $\sim 36^{\circ}$ to the SSW while thin silts and clay layers in sequence Q1 dip as much as $22^{\circ}$ to the SSW. An angular unconformity (Q1Q2 unconformity; yellow line on Figure 14) separates sequence Q1 from an overlying sequence of recessional outwash deposits (sequence Q2). Sequence Q2 consists of yellow brown to olive gray gravelly sandy loam, sandy loam, sandy clay, and clay (Figure 14). All of sequence Q2 is essentially flat-lying to very gently south-dipping.

A second unconformity separates sequence Q2 from an overlying gravelly deposit (Q2H/Q3 unconformity; green line on Figure 14). This unconformity is flat-lying between 8 and 16 meters (see Figure 14) and rises slightly between 2 and $6 \mathrm{~m}$. This slight rise could result either from a tectonic origin for the unconformity or from normal erosional processes that created the unconformity. Three conformable units lie above the Q2-H/Q3 unconformity.

Unit H/Q3 is an olive brown sandy loam that lies directly over the Q2-H/Q3

unconformity. This unit extends the length of the excavation but thins considerably in the northeastern part of the excavation. Dark brown organic-rich sandy loams (unit H4 and H4.1) overlie unit H/Q3 and most likely represent prehistoric and historic surface soils developed at the site. Charcoal samples collected at the base of unit H4 yielded AMS ages of 2450 $\pm 40 \mathrm{C} 14 \mathrm{yr}$ B.P. (BETA-200523; 2730 to 2350 cal yr B.P.) and 2660 \pm 50 C14 yr B.P. (BETA- 200524; 2850 to 2740 cal yr B.P.). Unit H4.1 is slightly disturbed in places, most likely by equipment used to place fill over the site in the early part of the $20^{\text {th }}$ century.

\section{EVIDENCE FOR PREHISTORIC DEFORMATION}

Stratigraphic and structural observations collected from the four excavations yield insights into past earthquakes along the SWIFZ (Figure 16). We mapped each excavation in 
detail, looking for evidence of surface deformation from folding and faulting and establishing criteria to distinguish tectonic from glacial deformation. Evidence for strong shaking at each site, in the form of liquefaction features, was also mapped. At sites along the Crystal Lake lineament, we observed evidence for past folding and faulting, and at sites along the Little Bear Creek lineament we observed evidence for past folding, faulting, and liquefaction. These past folding, faulting, and liquefaction events were each assigned a unique identifier and are discussed below.

Crystal Lake lineament

The clearest indication of prehistoric deformation along the Crystal Lake lineament is post-glacial folding (Event C) and a normal fault that offsets glacial deposits (Event B). Event B is interpreted from deformed drift and outwash cut by a low-angle normal fault (Figure 11). A low-angle fault observed in the Mountain Beaver excavation (dip is $\sim 20^{\circ}$ on Figures 9 and 11) separates Vashon drift/ablation till (Qd) from Vashon recessional outwash deposits (Qrs channel fill). The fault truncates interbeds within Qd. Drag folds in Qd and Qrs suggest a normal sense of movement on the fault (Figure 11). Stratigraphic observations suggest that the last episode of movement on the fault could be as old as late Pleistocene, and was possibly caused by syn- or post-depositional slumping or tectonic movement. The sediments cut by the normal fault are strongly deformed and are associated with features of soft-sediment deformation. Therefore, it is likely that Event B and the normal fault are the result of slumping or landsliding in a saturated, recessional-outwash environment rather than tectonic deformation. However, a tectonic origin for the normal fault cannot be ruled out completely.

After Event B, the entire section, including the fault, was warped by several meters of north-side-up folding. If the normal fault was created by landsliding during Event $B$, then the original dip of the fault plane may have been quite low or even flat, accounting for the $\sim 20^{\circ}$ postfolding dip of the fault plane. Post-glacial folding (Event C) along the Crystal lake lineament is indicated by dipping laminated silt layers, deformed recessional outwash deposits, and a buried soil. Laminated silts observed in the Flying Squirrel and Mountain Beaver excavations had dips averaging about $10^{\circ}$ in both excavations, but higher dips in parts of both excavations suggest post-depositional warping. Below the scarps at both excavations, dips of the silt layer increase, reaching a maximum of almost $40^{\circ}$ in the Flying Squirrel excavation and $\sim 30^{\circ}$ in the Mountain Beaver excavation (Figures 10 and 11 ). While $10^{\circ}$ dips may be common in glacial deposits, dips of laminated silts exceeding $30^{\circ}$ are not common; suggesting that the higher dips resulted from post-depositional deformation. Folding in the Mountain Beaver excavation is mirrored by dips of units Qvt, Qste, Qd, and Qrs, and the normal fault described above - suggesting that the entire section was warped during a single event. Geometry of stratigraphic sections in the Mountain Beaver excavation indicates that warping was greater than $2 \mathrm{~m}$ during Event 2 . Thus, the original scarp at the Mountain Beaver site likely was at least $2 \mathrm{~m}$ high. It is possible that the Mountains Beaver excavation records only Event C. Lidar profiles across the scarp show that the present-day scarp height is between 2.5 to $4 \mathrm{~m}$, suggesting that folding during Event $\mathrm{C}$ could have been $4 \mathrm{~m}$ high. Over time, the original scarp at the Mountain Beaver site degraded and colluvium buried the former soil at the base of the scarp (unit Hab on Figure 10).

Unit Hab at the Mountain Beaver site is a buried A-horizon. Filled root cavities extend from the bottom of the former soil horizon into the underlying units. The surface of the buried soil rises slightly towards the scarp, suggesting that parts of the former soil were eroded over time. Colluvium from the scarp (units Hc and Hcs) buried the remaining soil after the event. Thus, radiocarbon ages from charcoal in the buried soil horizon provide a maximum age for the 
timing of the folding event described above. A single radiocarbon age from a sample collected near the middle of unit Hab yielded an age of 12,090 - 11,670 cal yr B.P. This single age indicates that Event $\mathrm{C}$ occurred after 11,670 cal yr B.P.

\section{Little Bear Creek lineament}

Observations of fractures, faults, and shear zones in the French Onion excavation suggest a complex deformation history. We observed at least three structural fabrics in the excavation, one dipping to the south, one to the north, and a subhorizontal fabric. When viewed in outcrop, these fabrics give the older glacial units (Qscl, Qmud, Qmcl) a shattered appearance. We observed each fabric in the older glacial units and traced only a few faults into the overlying Holocene units. However, it was not possible to determine if the faults actually offset the Holocene units or if the Holocene units were simply weathering into one of the older faulted units. With few exceptions, we could not determine the sense of motion of any of the faults. We infer that the south and north-dipping fabrics are older than the subhorizontal fabric (discussed below). We did not assign any events to these fabrics because it is likely that none of the faults observed in the French Onion excavation moved after Vashon deglaciation. It is possible that fault-line erosion created the scarp at the French Onion site rather than movement on a fault.

The south-dipping fabric in the French Onion excavation is concentrated in the southern part of the excavation (Figure 13). We observed reverse motion on at least three of the southdipping faults. One of the south-dipping reverse faults cuts a late Quaternary till (Qt between 13 and $14.5 \mathrm{~m}$ on Figure 13). Several south-dipping faults appear to push Qscl against Qmud (between 7 and $10 \mathrm{~m}$ on Figure 13), suggesting a reverse sense of motion on this set of faults. These south-dipping reverse faults are difficult to explain with movement of glacial ice across the region. Glacial flutes indicate that ice flowed approximately north to south across the region in the last glacial advance, and we assume that previous glaciers flowed in similar directions. If these faults are glaciotectonic, then the hanging wall was thrust upwards into the bed of the glacier - an unlikely scenario. More likely, the south-dipping faults are tectonic and were later cut by north-dipping and subhorizontal faults produced by movement of glacial ice.

The north-dipping fabric is concentrated in the northern part of the excavation. The largest of the faults observed in this set of features appear to merge between grid points 9 and 10 $\mathrm{m}$ on Figure 13. Bedding truncations and displacements on the largest of the north-dipping faults were not observed so it is not possible to indicate a sense of slip for this set of features.

A subhorizontal shear fabric cuts across the north-dipping and south-dipping faults in the French Onion excavation. Microfaults observed in the subhorizontal fabric had both reverse and normal displacements, but were dominated by normal displacement. In general, the sense of net tectonic transport was to the south. A south-directed tectonic transport is consistent with the subhorizontal fabric resulting from simple shear at the base of a glacier. Nelson at al. (2003) observed similar shear fabrics developed in weathered bedrock immediately below Vashon till and attributed the shears to movement of glacial ice across the weathered bedrock surface.

The Beef Barley excavation has a rich history of deformation and strong ground shaking. One or possibly two angular unconformities and reverse faulting suggest multiple episodes of surface deformation. Liquefaction features observed throughout the excavation disturb recent soils and indicate strong ground shaking in the late Holocene.

The oldest period of deformation (Event D) in the Beef Barley excavation is marked by the angular unconformity between sequences Q1 and Q2 (Figures 14 and 15). Although no material was found to provide ages for either sequence, lithologic comparisons to other exposures and the lack of overconsolidation suggest that the unconformity separates two 
sequences of Vashon recessional outwash. We speculate that the unconformity was created when an earthquake on the Little Bear Creek lineament caused folding of sequence Q1 (Event D). Following Event D, the folded units were beveled off by flowing water and sequence Q2 was deposited. Thus, Event D likely occurred between deglaciation and establishment of nonglacial environments, or roughly between 16,400 and $\sim 12,000$ cal yr B.P. A limiting minimum age of 12,000 years B.P. was selected because non-glacial environments were established in many areas of the Puget Lowland by 12,000 years B.P. (Nelson and others, 2003; Sherrod, 2002). Non-glacial environments inferred at the Mountain Beaver site at the time of Event $C$ suggest that Event C postdates Event D by hundreds to thousands of years (Figure 16).

A possible earthquake (Event E) occurred in either the latest Pleistocene or early Holocene, marked in the Beef Barley excavation by the unconformity between sequence Q2 and unit H/Q3. This unconformity could be the result of folding on the Little Bear Creek lineament, or, alternatively, the unconformity could be the result of normal fluvial processes acting at the site at the time unit H/Q3 was deposited. Neither alternative can be dismissed based on the data collected in the excavation. If the unconformity is the result of folding on the Little Bear Creek lineament, no age data exist to constrain the age of the event beyond being younger than $\sim 12,000$ yr B.P and older than 2850 cal yr B.P., the maximum age of unit H4.

The youngest event (Event F) recorded in the Beef Barley excavation included folding, reverse faulting, and liquefaction. Evidence for folding is best seen between 14 and $20 \mathrm{~m}$ on the excavation logs (Sherrod et al. (2005), and Figure 15). Reverse faulting is best seen between 13.5 and $15 \mathrm{~m}$ on the excavation logs. Good piercing points to measure displacement during this youngest event are lacking but the folding probably did not exceed 1 meter and the faulting is likely limited to only a few decimeters (less than $30 \mathrm{~cm}$ ). However, none of these estimates account for out-of-plane movement (lateral displacement), and actual slip could have been quite a bit larger.

Liquefaction accompanied the folding and faulting of the youngest event, evidenced by numerous liquefaction features observed throughout the excavation (Figures 14 and 15). These features include sand-filled dikes injected upwards through fine-grained facies of sequences Q1 and Q2. Pieces of Q1 and Q2 were entrained by the flow of sand, including blocks of silt in a large liquefaction feature between 13.5 and 16 meters on the log (Figure 15). The liquefaction is associated with and may have taken advantage of the reverse faults observed between 14 and 15 meters, suggesting that the faulting and liquefaction occurred during the same event. Alternatively, it is possible that the faults created during an older event were places of weakness followed by younger liquefaction features. That the liquefaction is young is also evidenced by the degree to which unit H4 is disturbed by the liquefaction. Units H/Q3 and H4 were deformed into hummocks and swales above the liquefaction features, and one sand dike was observed cutting through units $\mathrm{H} 4$ and H4.1 to the former land surface. Since the liquefaction disturbs unit $\mathrm{H} 4$, the events that caused the shaking had to postdate the youngest charcoal collected from H4, or about $2730 \mathrm{cal}$ yr B.P. It is possible that multiple events in the late Holocene caused strong ground shaking at the Beef Barley site. Bourgeois and Johnson (2001) documented at least three episodes of liquefaction in the late Holocene at the Snohomish River delta, about $26 \mathrm{~km} \mathrm{~N} / \mathrm{NW}$ of the site. Any of these events could also have shaken the ground hard enough at the Beef Barley site to generate the liquefaction features observed in the excavation.

In this study, liquefaction is unique to the Beef Barley site. Site conditions explain why the Beef Barley site liquefied while the other sites did not. Saturated soils and groundwater are located near the ground surface at the Beef Barley site. Near surface soils at the Beef Barley site 
include fine-grained sediments likely to act as a barrier to upwards flow of liquefied materials. None of the other excavation sites contained the unique set of conditions conducive to liquefaction that are found at the Beef Barley site.

\section{STRUCTURE AND PREHISTORIC EARTHQUAKES ON THE SWIFZ}

Offshore marine seismic surveys indicate that several strands of the SWIFZ traverse Admiralty Inlet and Whidbey Island before making landfall between the cities of Edmonds and Mukilteo (Figure 17). The magnetic survey data presented in Blakely et al. (2004) and in this report show that after making landfall, strands of the SWIFZ continue to the southeast and cross through southern Snohomish County and northern King County near Maltby and Woodinville. Lidar mapping shows that scarps on the ground surface lie on or near several magnetic anomalies, suggesting that the shallow subsurface anomalies are strands of an active fault zone. Excavations across two scarps confirm that the Crystal Lake and Little Bear Creek lineaments are active strands of the SWIFZ.

We envision one model of the SWIFZ as a set of anastomosing faults, two of which are the Crystal Lake and the Little Bear Creek lineaments. These strands have lidar scarps and paleoseismological evidence that suggests earthquakes have ruptured the ground surface at least once in the Holocene. Other strands may be active as well, including Lineament "X" (Figure 9), the "GA anomaly" (Figure 4), and possible strands associated with scarp-like features identified on historical aerial photographs. However, poor quality of existing lidar coverage in King County and lack of lidar in southern Snohomish County preclude making any statements as to surface ruptures associated with these features. Based on the aeromagnetic mapping in southern Snohomish and King Counties, the SWIFZ could exceed $12 \mathrm{~km}$ in width, but at present, active strands are only known between Woodinville and Maltby (Figures 6 and 17).

Prehistoric earthquake activity on at least two strands of the SWIFZ is based on excavations across scarps identified on lidar maps. These excavations, combined with published data from Whidbey Island (Kelsey and others, 2004), indicate that at least four earthquakes struck the SWIFZ in the last 16,400 years (labeled as events C, D, W, and F on Figure 16). An additional earthquake and at least three ground shaking events have occurred along the SWIFZ when additional excavation information and events from the Snohomish River delta are considered (Bourgeois and Johnson, 2001). The liquefaction events could have sources other than the SWIFZ, such as a large Seattle fault event about 1100 years ago and intraslab events (Bucknam and others, 1992). However, if we included the liquefaction events and other evidence as indicators of possible SWIFZ events, then the number of events in the last 16,400 years increases to nine (Figure 16).

\section{FUTURE RESAERCH DIRECTIONS}

We now have strong evidence that two fault strands in the Maltby-Woodinville area, presumably part of the SWIFZ, slipped multiple times in the Holocene, yet questions remain regarding the overall hazards posed by the SWIFZ. The focus of our present study and that of a previous report (Blakely and others, 2004) was controlled partly by available lidar coverage. As shown in Figure 6, that lidar survey did not include mainland regions along the Puget Sound, nor areas northeast of Maltby. Thus, we do not have a clear view of the length and width of the active deformation zone. This uncertainty could be addressed with new, high-quality lidar surveys and follow-on trench excavations. The region between Maltby and Snohomish is of particular interest because of lineaments noted in airborne photography, many of which 
correspond to aeromagnetic anomalies.

The region between the Little Bear Creek lineament and Lake Washington is also an important concern. Numerous northwest-striking aeromagnetic lineaments have been interpreted in this region, but corresponding scarps have not been identified. Several explanations are possible: (1) The aeromagnetic lineaments may reflect sub-surface faults that have no topographic expression, either because slip surfaces did not intersect the ground or because the ground surface has been altered by human development or by geologic processes occurring subsequent to latest slip. (2) The lidar data may have been of insufficient quality to detect small scarps. (3) The aeromagnetic lineaments may be caused by geologic processes other than faulting and thus pose no hazard. An experimental trench across a well-defined aeromagnetic lineament, one without topographic expression, might determine which explanation is most plausible.

Questions also remain regarding the vertical extent and three-dimensional aspects of individual fault strands. High-resolution seismic-reflection profiles conducted across selected lineaments might define the configuration of deformed strata and the amounts of vertical offset on faults at depth. Additional ground-magnetic surveys, analyzed jointly with existing aeromagnetic anomalies, might help determine the vertical extent of identified faults. Ground magnetic surveys are impractical throughout much of the study region, however, because of the proximity of manmade structures. A helicopter-borne magnetic survey, flown as low as safely possible and along closely spaced flight lines, would serve as an excellent alternative.

\section{ACKNOWLEDGEMENTS}

The U.S. Geological Survey National Earthquake Hazards Reduuction Program and an Inter-Agency Agreement between the U.S. Geological Survey and King County, Washington provided funding for this project.

\section{REFERENCES CITED}

Aspect Consulting, 2005, North Mitigation Area Trench Boring Investigation Summary Brightwater Treatment Plant Seismicity Investigation: Consultant report prepared for CH2M Hill.

Blakely, R.J., 1995, Potential theory in gravity and magnetic applications, Cambridge University Press, $441 \mathrm{p}$.

Blakely, R.J., Sherrod, B.L., Wells, R.E., Weaver, C.S., McCormack, D.H., Troost, K.G., and Haugerud, R.A., 2004, The Cottage Lake aeromagnetic lineament: a possible onshore extension of the southern Whidbey Island fault, Washington, in U.S.G.S., ed., p. 60.

Blakely, R.J., Wells, R.E., and Weaver, C.S., 1999, Puget Sound Aeromagnetic Maps and Data: U.S. Geological Survey Open-File Report 99-514, 4 p.

Blakely, R.J., Wells, R.E., Weaver, C.S., and Johnson, S.Y., 2002, Location, Structure, and Seismicity of the Seattle Fault Zone, Washington: Bulletin of the Geological Society of America, v. 114, p. 169-177.

Bourgeois, J., and Johnson, S.Y., 2001, Geologic evidence of earthquakes at the Snohomish delta, Washingotn, in the past 1200 yr: Geological Society of America Bulletin, v. 113, no. 4, p. 482-494.

Brocher, T.M., Parsons, T., Blakely, R.A., Christensen, N.I., Fisher, M.A., Wells, R.E., and Group, S.W., 2001, Upper crustal structure in Puget Lowland, Washington: Results from 1998 Seismic Hazards Investigation in Puget Sound: Journal of Geophyisical Research, 
v. 106, p. 13,541-513,564.

Bucknam, R.C., Hemphill-Haley, E., and Leopold, E.B., 1992, Abrupt uplift within the past 1700 years at southern Puget Sound, Washington: Science, v. 258, p. 1611-1614.

Collins, B., Sheikh, A., Montgomery, D., Kiblinger, C., Greenberg, H., and Biggs, D., 2005, Puget Sound River History Project, http://riverhistory.ess.washington.edu/index.html, University of Washington.

Gower, H.D., Yount, J.C., and Crosson, R.S., 1985, Seismotectonic map of the Puget Sound region, Washington: U.S. Geological Survey Miscellaneous Investigations Series Map I1613, 15 p.; 250,000.

Johnson, S.Y., Potter, C.J., Armentrout, J.M., Miller, J.J., Finn, C.A., and Weaver, C.S., 1996, The southern Whidbey Island Fault; an active structure in the Puget Lowland, Washington: Geological Society of America Bulletin, v. 108, no. 3, p. 334-354.

Kelsey, H.M., Sherrod, B., Johnson, S.Y., and Dadisman, S.V., 2004, Land-level changes from a late Holocene earthquake in the northern Puget Lowland, Washington: Geology, v. 32, no. 6, p. 469-472.

Kelsey, H.M., Sherrod, B.L., Johnson, S.Y., and Dadisman, S.V., 2004, Land-level changes from a late Hoocene earthquake in the northern Puget Lowland, Washington: Geology, v. 32, no. 6, p. 469-472.

Minard, J.P., 1985, Geologic map of the Maltby quadrangle, Snohomish and King Counties, Washington: U. S. Geological Survey Miscellaneous Field Studies MF-1746, 1:24,000.

Nelson, A.R., Johnson, S.Y., Kelsey, H.M., Sherrod, B.L., Wells, R.E., Okumura, K., Bradley, L.-A., Bogar, R., and Personius, S.F., 2003, Field and laboratory data from an earthquake history study of the Waterman Point fault, Kitsap County, Washington: U.S. Geological Survey Miscellaneous Field Studies Map MF-2423.

Nelson, A.R., Johnson, S.Y., Kelsey, H.M., Wells, R.E., Sherrod, B.L., Pezzopane, S.K., Bradley, L.A., Koehler, R.D., III, and Bucknam, R.C., 2003, Late Holocene earthquakes on the Toe Jam Hill fault, Seattle fault zone, Bainbridge Island, Washington: Geological Society of America Bulletin, v. 115, no. 11, p. 1388-1403.

Peters, L.J., 1949, The direct approach to magnetic interpretation and its practical application: Geophysics, v. 14, p. 290-320.

Porter, S.C., and Swanson, T.W., 1998, Radiocarbon age constraints on rates of advance and retreat of the Puget lobe of the Cordilleran ice sheet during the last glaciation: Quaternary Research, v. 50, p. 205-213.

Ramachandran, K., Hyndman, R.D., and Brocher, T.M., 2005, Northern Cascadia subduction zone: tomographic 3D P-wave velocity structure: Geophysical Journal International, v. in press.

Rau, W.W., and Johnson, S.Y., 1999, Well stratigraphy and correlations, western Washington and northwestern Oregon: U.S. Geological Survey Geologic Investigations Series Map I2621, $31 \mathrm{p}$.

Sherrod, B.L., 2002, Late Quaternary Surface Rupture Along the Seattle Fault Zone Near Bellevue, Washington: Eos Trans. AGU, Fall Meet. Suppl., v. 83, no. 47, p. Abstract S21C-12.

Sherrod, B.L., Barnett, E., and Kelsey, H.M., 2005, Excavation Logs of Two Trenches Across a Strand of the Southern Whidbey Island Fault Zone Near Grace, Washington: U.S. Geological Survey Open-File Report 2005-1013, p. 36x48 oversized sheet.

Tabor, R.W., Frizzell, V.A., Jr., Booth, D.B., Waitt, R.B., Jr., Whetten, J.T., and Zartman, R.E., 
1993, Geologic map of the Skykomish River 30-minute by 60-minter quadrangle, Washington: U. S. Geological Survey Map I-1963.

Wells, R.E., and Simpson, R.W., 2001, Northward migration of the Cascadia forearc in the northwestern U.S. and implications for subduction deformation: Earth, Planets, and Space, v. 53, p. 275-283.

Wells, R.E., Weaver, C.S., and Blakely, R.J., 1998, Fore-arc migration in Cascadia and its neotectonic significance: Geology, v. 26, no. 8, p. 759-762.

Yount, J.C., and Gower, H.D., 1991, Bedrock geologic map of the Seattle 30x60 quadrangle, Washington: U. S. Geological Survey Open File Report 91-147. 

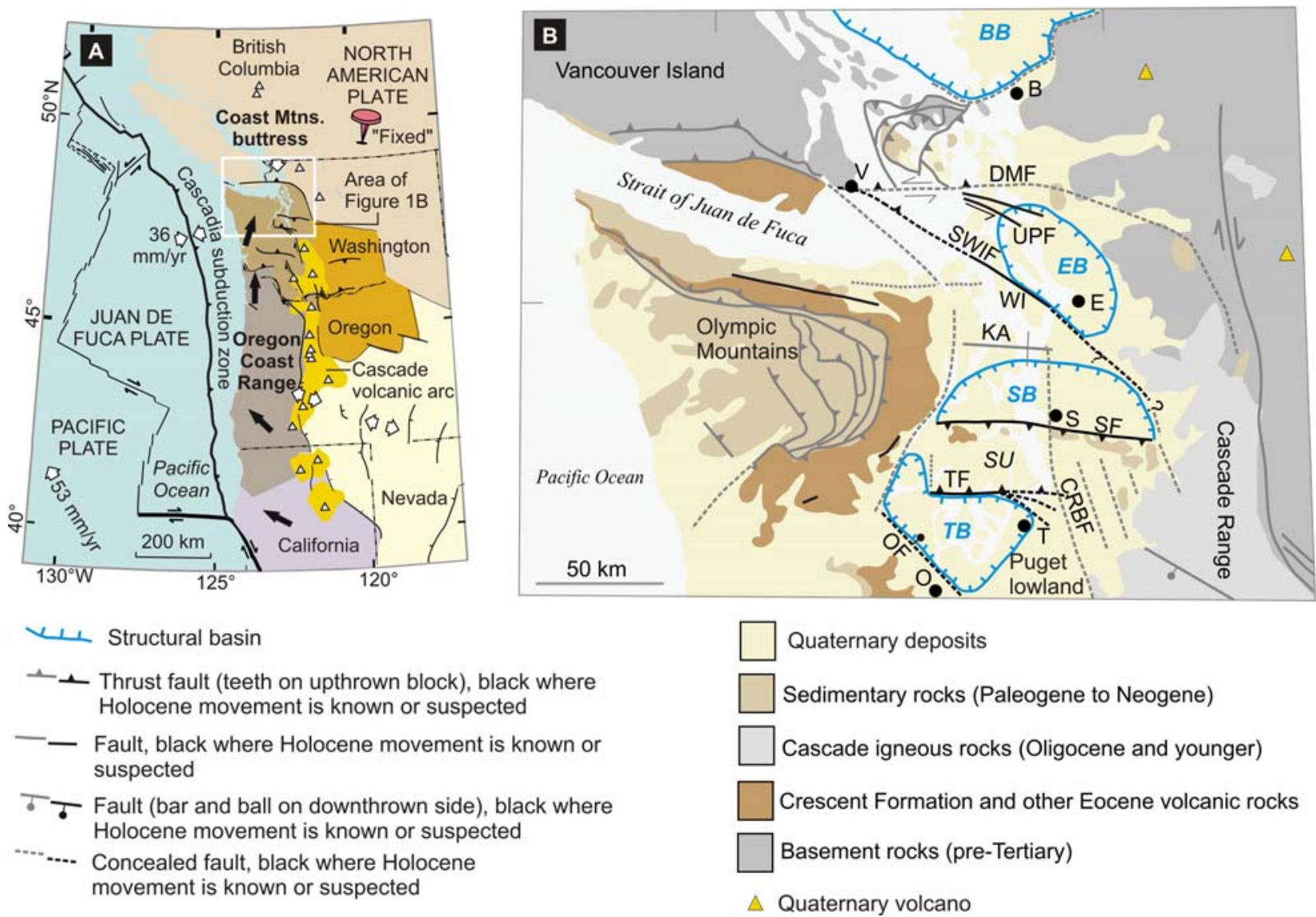

Figure 1-(A) Kinematic model of Cascadia forearc, simplified from Wells and others (Wells and others, 1998) and Wells and Simpson (2001). Northward migration of the Oregon Coast Range squeezes western Washington against North America, producing faults and earthquakes in the Puget Lowland. (B) Generallized map of the Puget Lowland and surrounding regions. BB, Bellingham basin; EB, Everett basin; SB, Seattle basin; TB, Tacoma basin; DMF, Devils Mountain fault; UPF, Utsalady Point fault; SWIF, southern Whidbey Island fault; SF, Seattle fault; TF, Tacoma fault; OF, Olympia fault; V, Vancouver; B, Bellingham; E, Everett; S, Seattle; T, Tacoma; O, Olympia; WI, Whidbey Island; KA, Kingston arch; SU, Seattle uplift. Redrawn from Brocher and others (2001). 


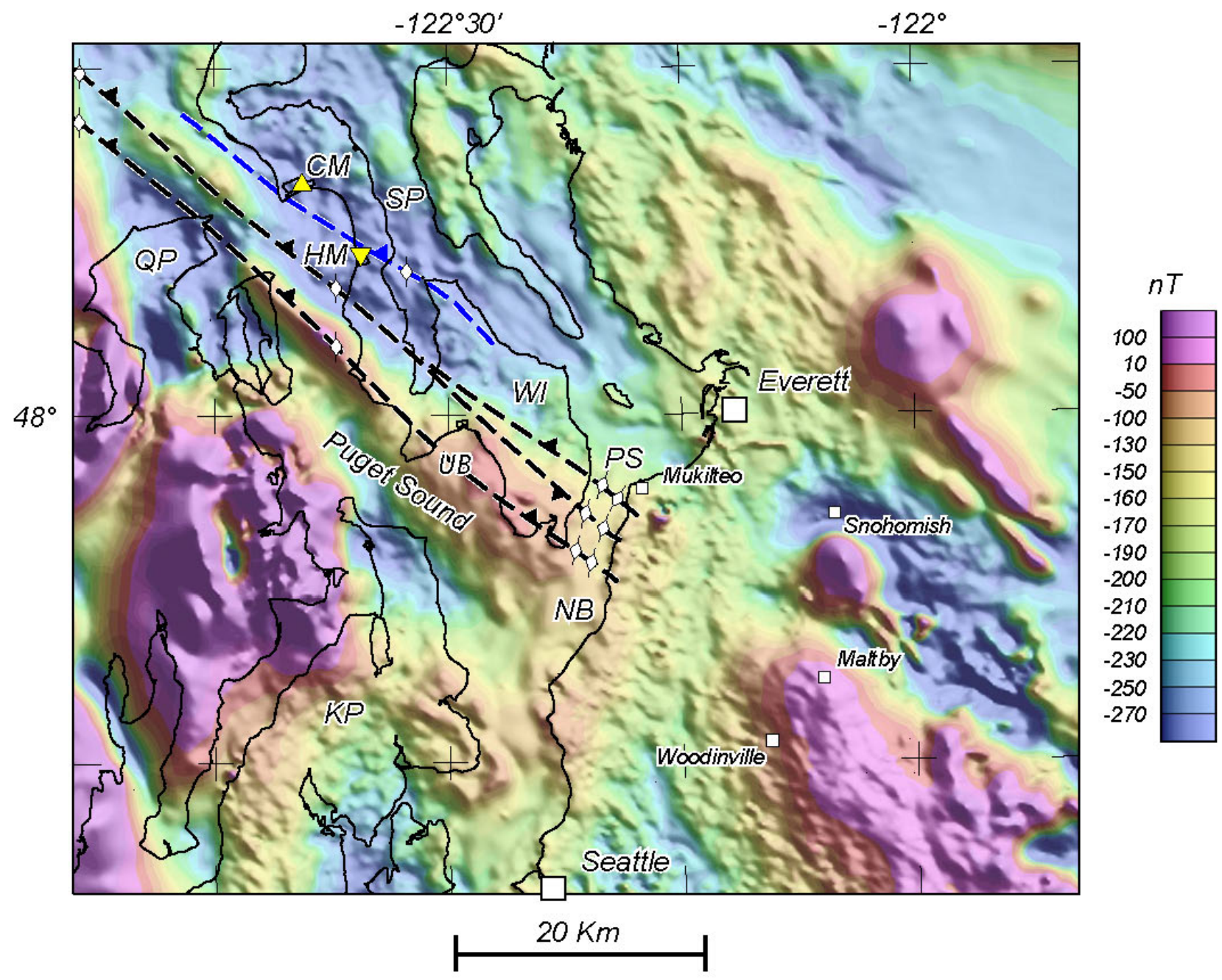

Figure 2-Evidence for the SWIFZ. Color-shaded relief map indicates intensity of the magnetic field observed in a high-resolution aeromagnetic survey (Blakely and others, 1999). Dashed lines show faults from published reports: black lines from Johnson and others (1996) and blue lines from Kelsey and others (2004). White diamonds show approximate location of faults identified using marine seismic-reflection surveys. Yellow triangles indicate relative sea-level study sites (Kelsey and others, 2004); northern triangle (Crockett marsh) is up relative to the southern triangle (Hancock marsh). CM, Crockett marsh; HM, Hancock marsh; WI, Whidbey Island; SP, Saratoga Passage; PS, Possession Sound; QP, Quimper Peninsula; KP, Kitsap Peninsula; NB, Nora Beach, UB - Useless Bay.

Figure 3 (on following page) - (A) Aeromagnetic anomalies of the study area. Major roads indicated by brown lines. Labels A, B, C, D, and E refer to anomalies and lineaments discussed in text. GMS shows location of ground-magnetic survey. SA, Standard Oil Company of California Alderwood \#1 well; SS, Standard Oil Company of California Socal-Schroeder \#1 well. (B) Residual magnetic anomalies of study area. Upward-continuation distance $50 \mathrm{~m}$. White dots show the location of magnetic contacts determined automatically with the method of Blakely and Simpson (1986). Black dashed lines indicate lineaments associated with specific magnetic contacts; black dotted lines are lineaments identified with lower confidence. Color interval for both maps determined by an equal histogram algorithm. 


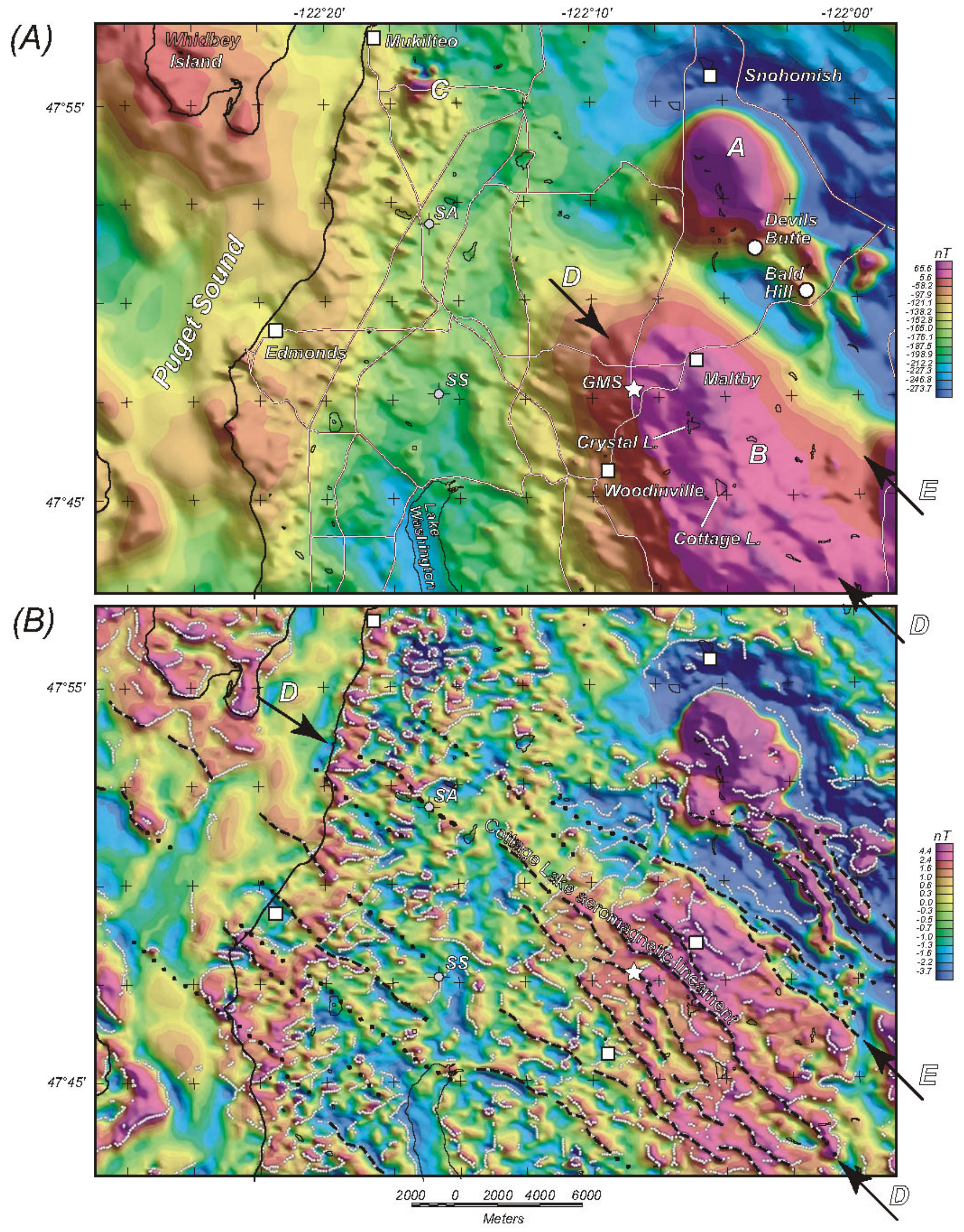




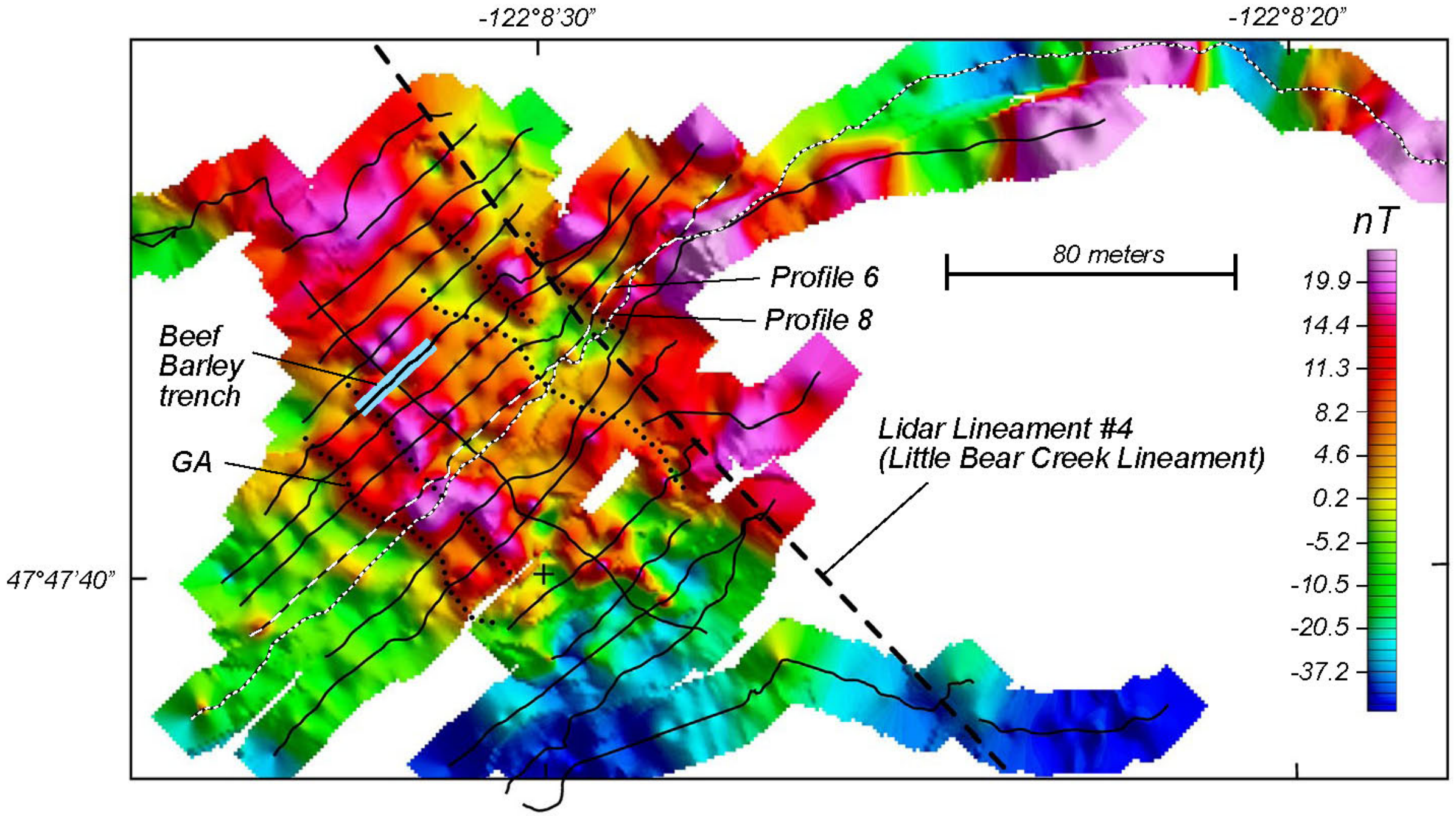

Figure 4-Ground-magnetic survey of the Beef Barley trench site. Thin black lines show location of profiles; profiles 6 and 8 (shown in Figure 5) highlighted with white dashes. Bold blue line is location of Beef Barley trench, and black dashed line is lidar lineament 4 from Blakely and others (2004). Black dotted lines indicate northwest-striking lineaments discussed in text; label GA is lineament referred to in text and identified in Figure 5. 
(A)

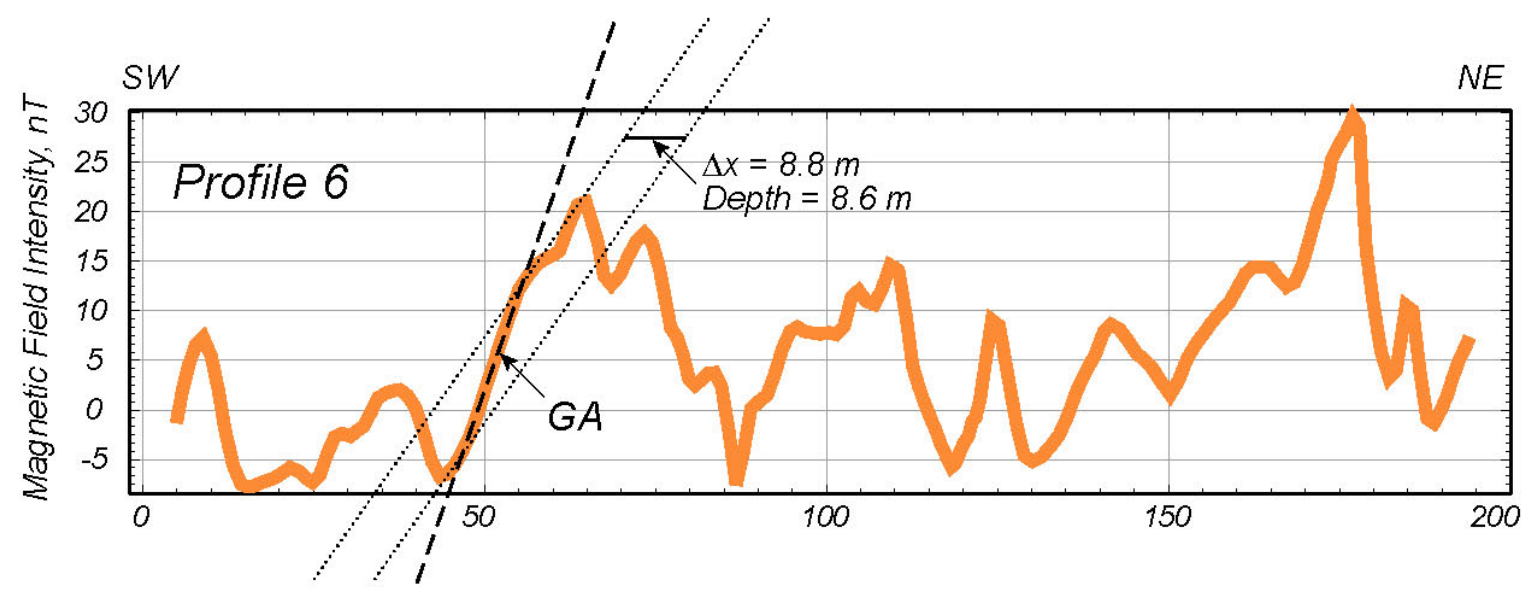

(B)

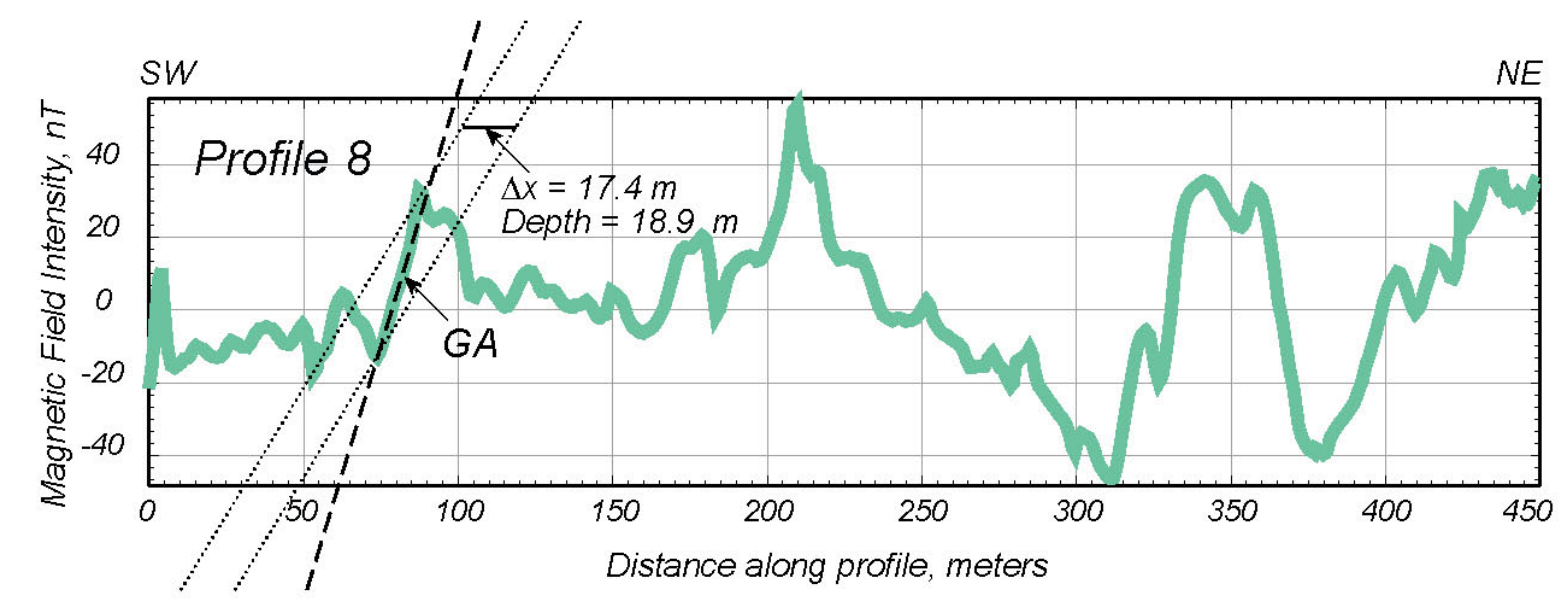

Figure 5-Profiles 6 and 8 of ground-magnetic survey (shown in Figure 4). See Figure 2 for location. Dotted and dashed lines show gradient analyzed using Peters' method (Peters, 1949; Blakely, 1995, p. 238), as discussed in text. Depth is relative to ground level.

Figure 6 (on following page)—Summary diagram showing locations of aeromagnetic anomalies, faults from marine seismic reflections data, lidar scarps, and lidar lineaments. SA, Standard Oil Alderwood\#1 well; SS; Standard Oil Socal-Schroeder \#1 well. 


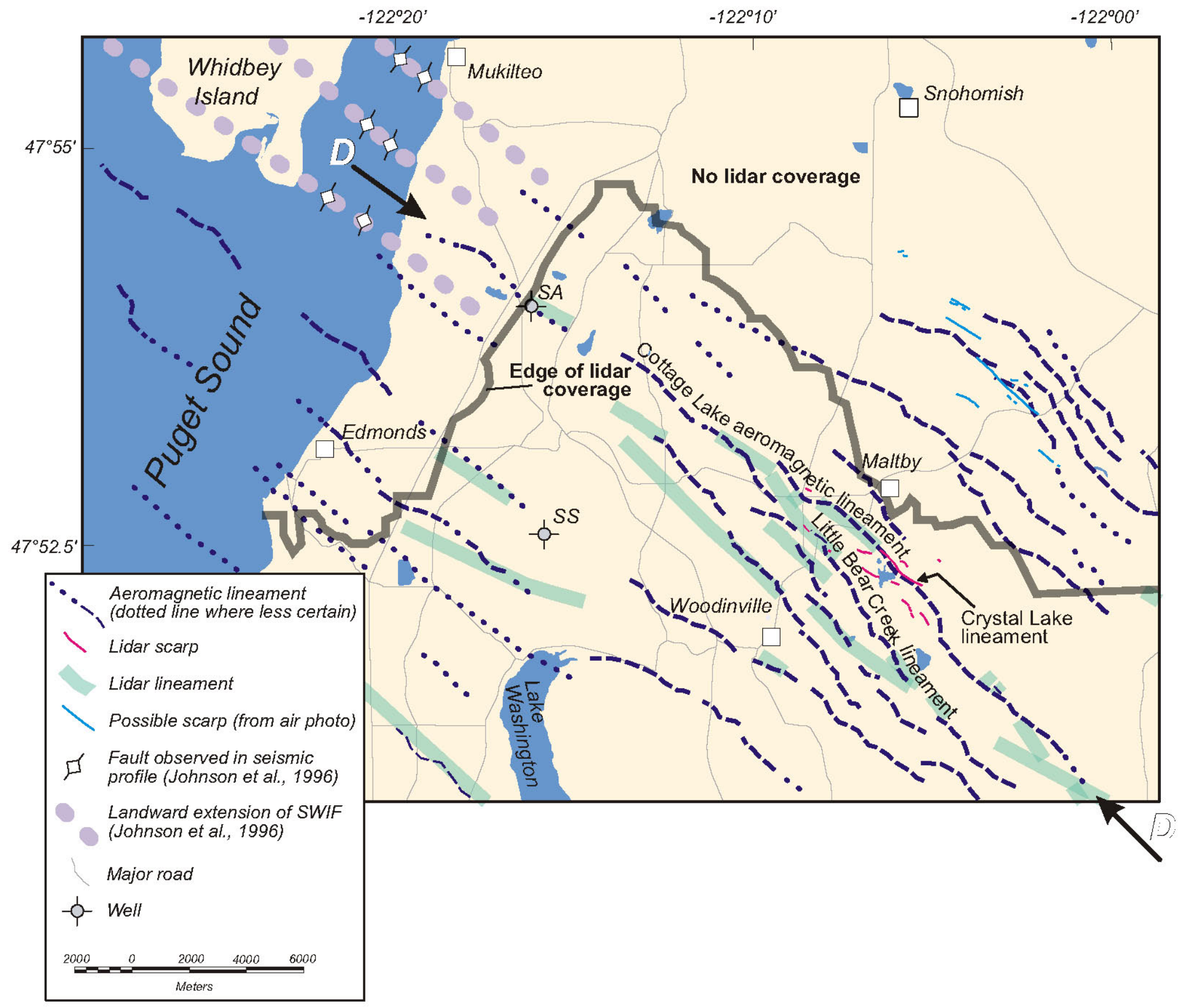




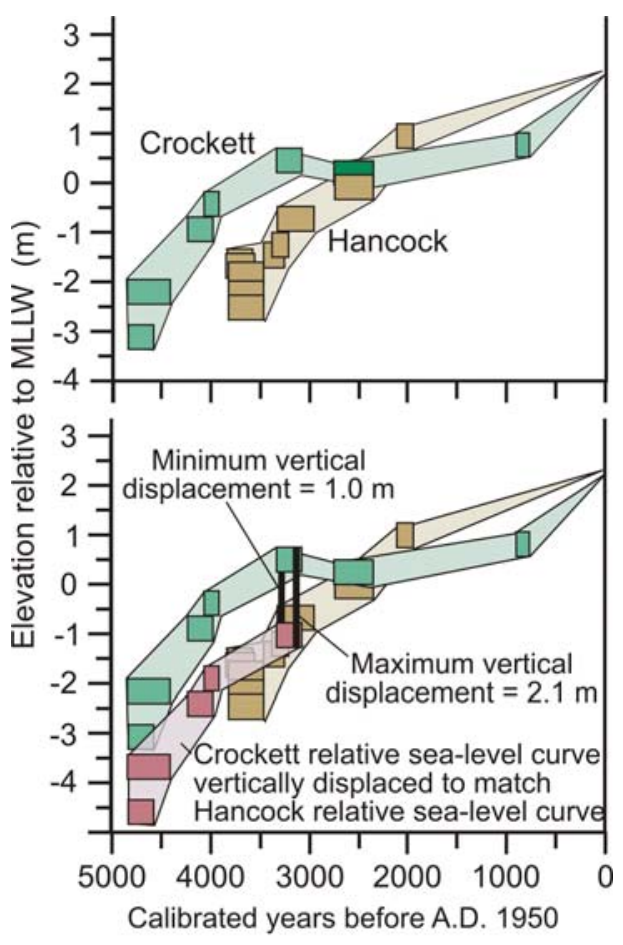

Figure 7-Relative sea-level histories from Crockett and Hancock marshes, Whidbey Island (Kelsey and others, 2004). The upper plot shows the actual sea level data, composed or radiocarbon ages from samples collected from the interface between marine and freshwater deposits beneath each marsh. The lower plot shows how much vertical displacement on the SWIFZ is required to offset the curves. 

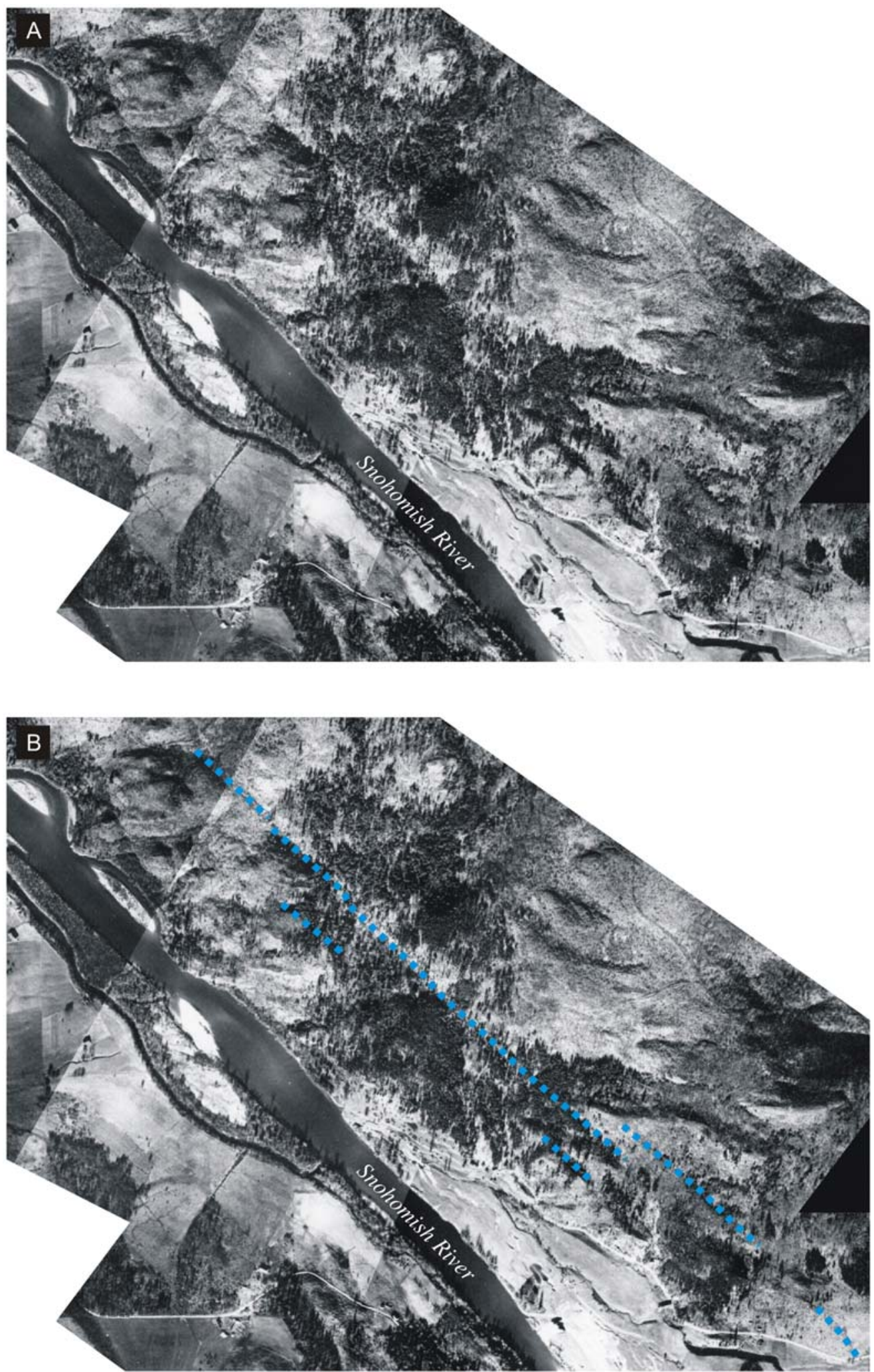

Figure 8-Historical aerial photographs along the Snohomish River near Devil's Butte. (A) Uninterpreted aerial photograph. (B) Interpreted aerial photograph. These photographs illustrate the types of features observed on the aerial photographs. In general, the scarps and lineaments have the same approximate trend as the SWIFZ and the aeromagnetic anomalies located nearby. 

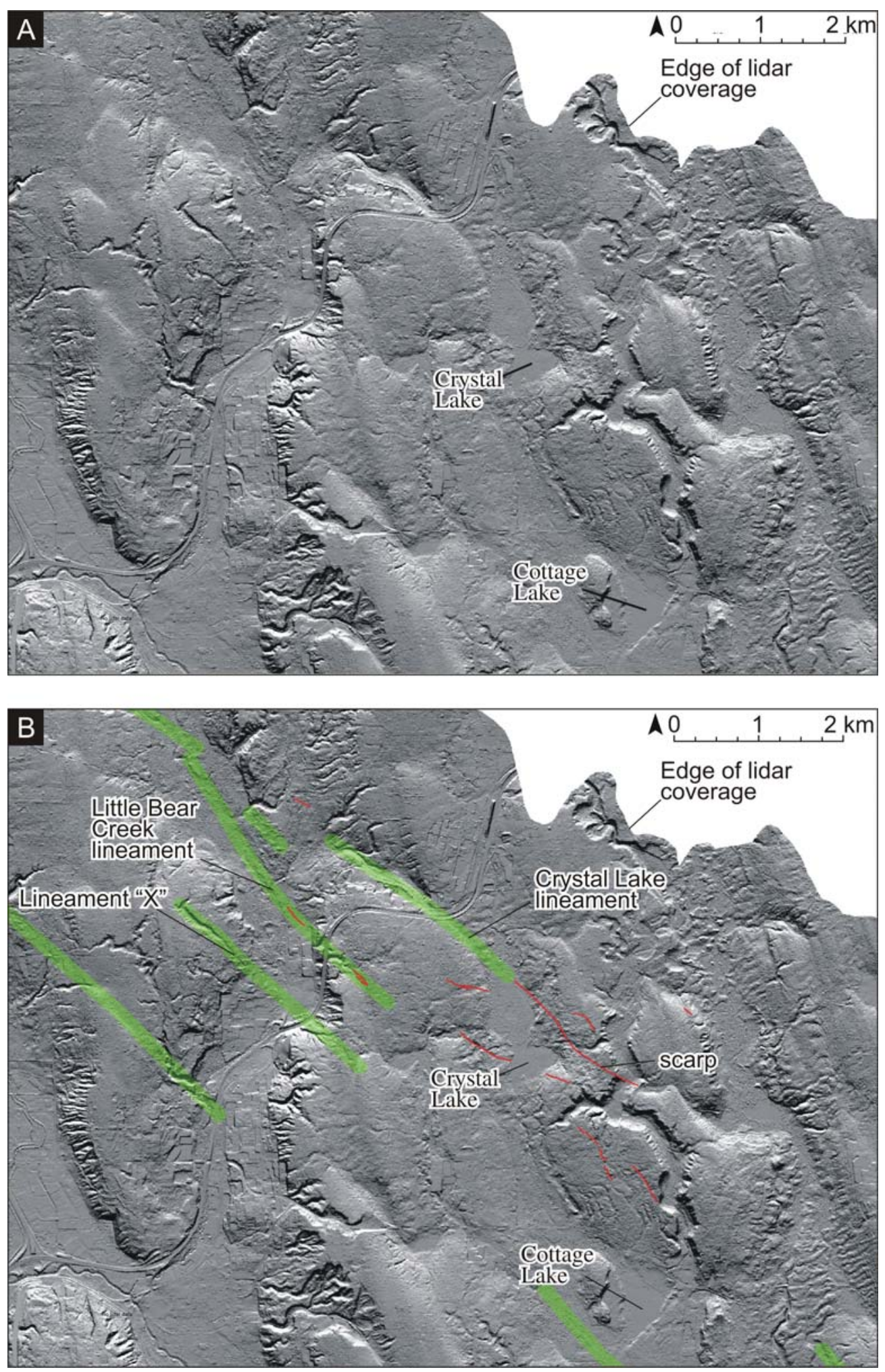

Figure 9-(A) Uninterpreted lidar image of the Crystal Lake and Little Bear Creek lineaments. (B) Interpreted lidar image of the Crystal Lake and Little Bear Creek lineaments. Thick green lines are lidar lineaments and thin red lines are lidar scarps. The scarp east of Crystal Lake is marked as 'scarp'. 


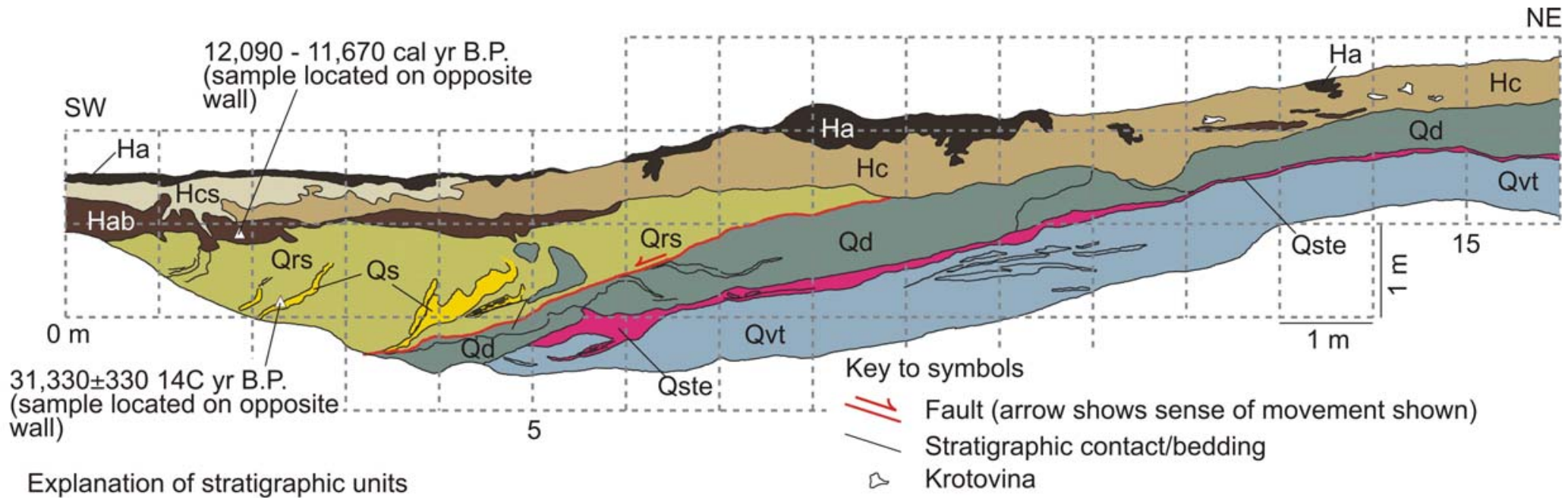

$\mathrm{Ha}$ Dark brown organic detritus -

modern forest litter

Hcs Light brown silty loam, root stirred -

Holocene scarp colluvium

Hc Light brown silty loam, krotovina -

Holocene colluvium

Hab Dark brown organic-rich sandy

loam - buried A-horizon

Qs Gray to brown med. to coarse sand Vashon recessional channel sands

Qrs Brown sandy silt with pebbles to silty sand Vashon recessional channel fill deposits

Gray, moderately dense, sandy silt with pebbles and cobbles - Vashon ablation till

Qste Gray, laminated, dense silt - Vashon silt

Gray, dense, gravelly sandy silt - Vashon till

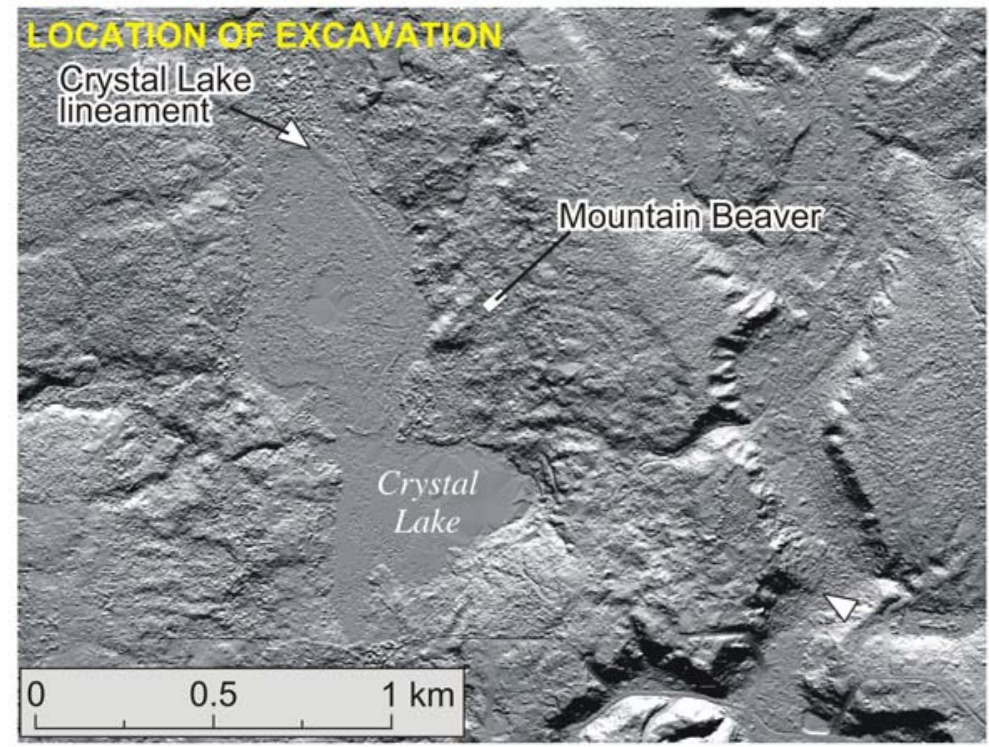

Figure 10—Simplified excavation log of the Mountain Beaver trench (east wall). (Inset) Lidar image showing the excavation site. Log is flipped relative to actual mapped log to aid intercomparison of excavation logs in this report. 

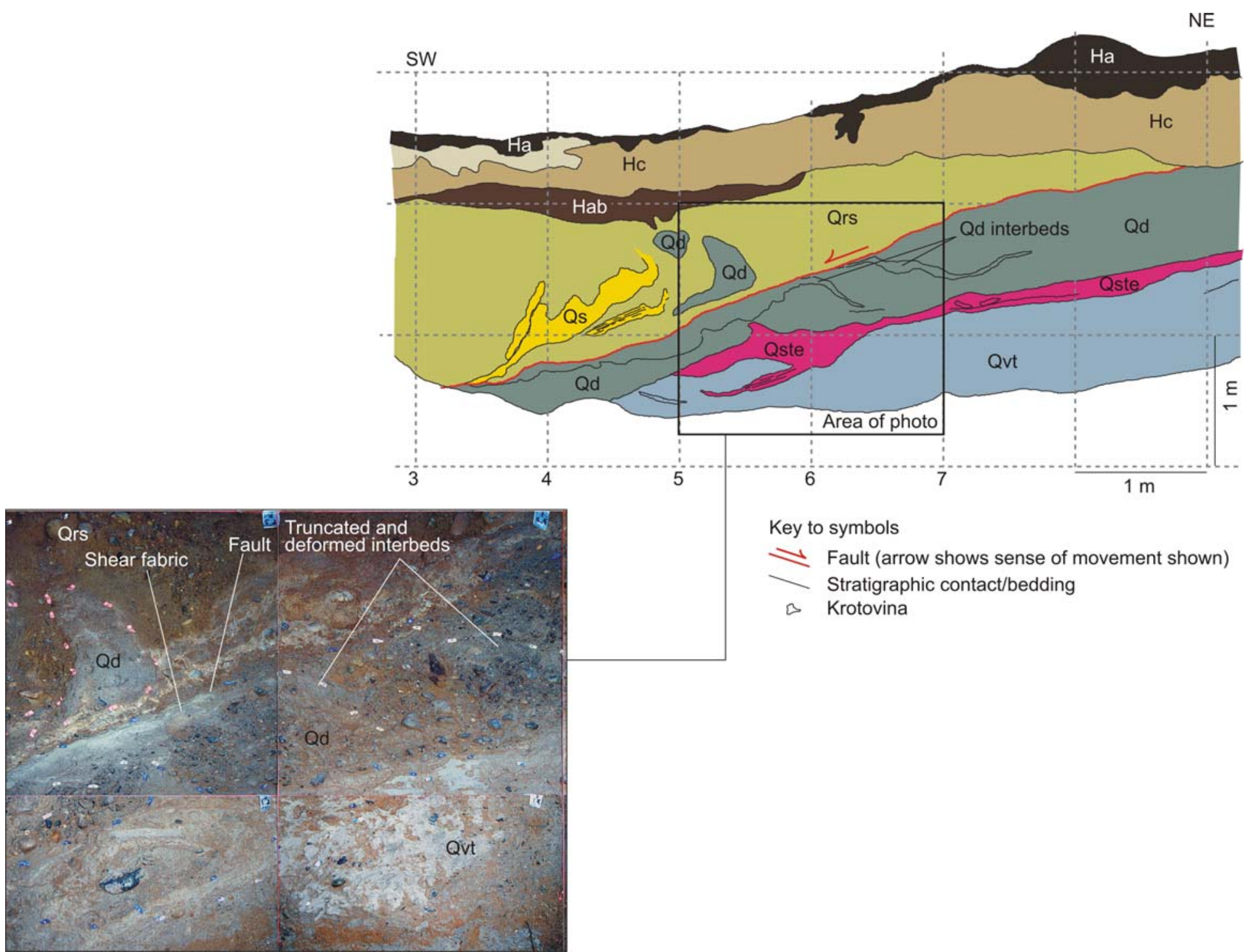

Key to symbols

$\sim$ Fault (arrow shows sense of movement shown)

Stratigraphic contact/bedding

¿ Krotovina

Figure 11—Enlarged excavation diagram showing the normal fault in the Mountain Beaver excavation. The photomosaic at the lower right shows an enlargement of the fault and truncated beds (photomosaic shows an area 2 meters wide). Log and photo are flipped relative to actual mapped log to aid intercomparison of excavation logs in this report. 


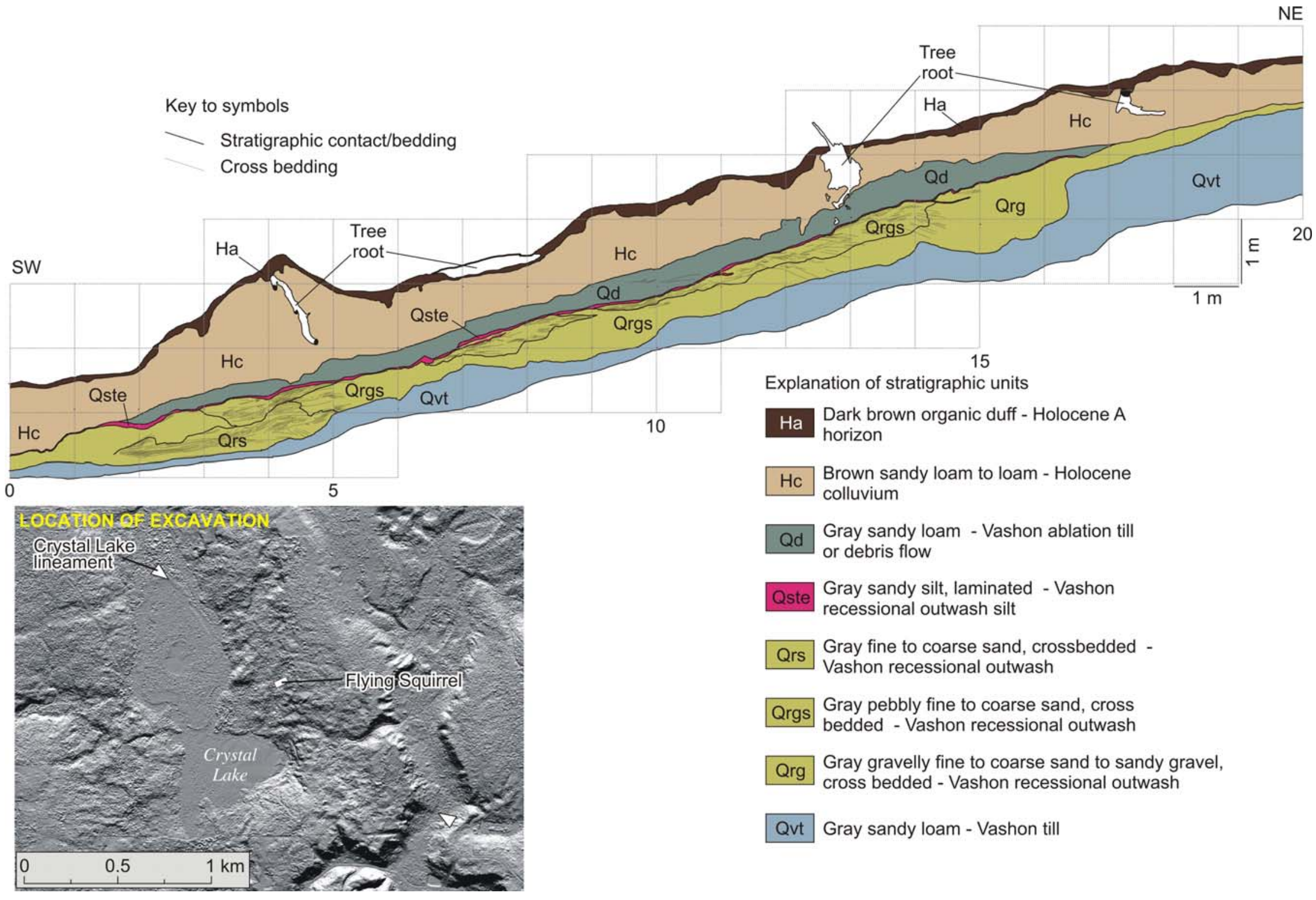

Figure 12- Simplified excavation log of the Flying Squirrel trench (west wall). (Inset) Lidar image showing the excavation site. 


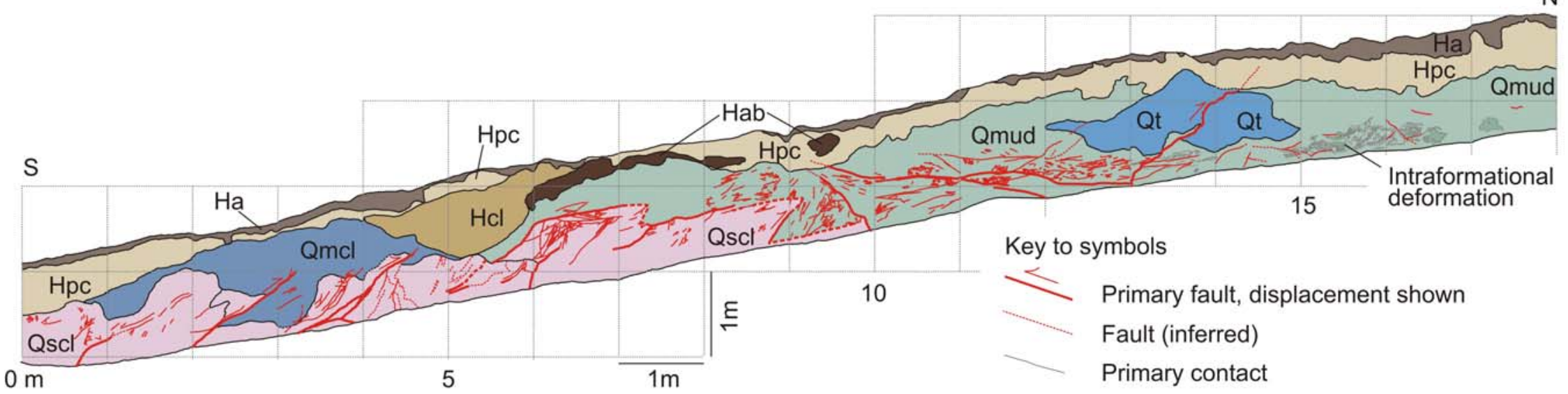

Explanation of stratigraphic units

$\mathrm{Ha}$ Dark brown organic duff - Holocene A

horizon

Hab Brown organic-rich, sandy loam to loam buried Holocene A horizon

Hpc Brown pebbly sandy loam to loam Holocene pebbly colluvium

$\mathrm{Hc}$ Brown sandy loam to loam - Holocene colluvium

Qt Brownish gray sandy loam to loam Quaternary till

Qmcl Gray massive to laminated claystone Quaternary glacial lake depositl

Qmud Brown shattered mudstone - Quaternary glacial lake deposits

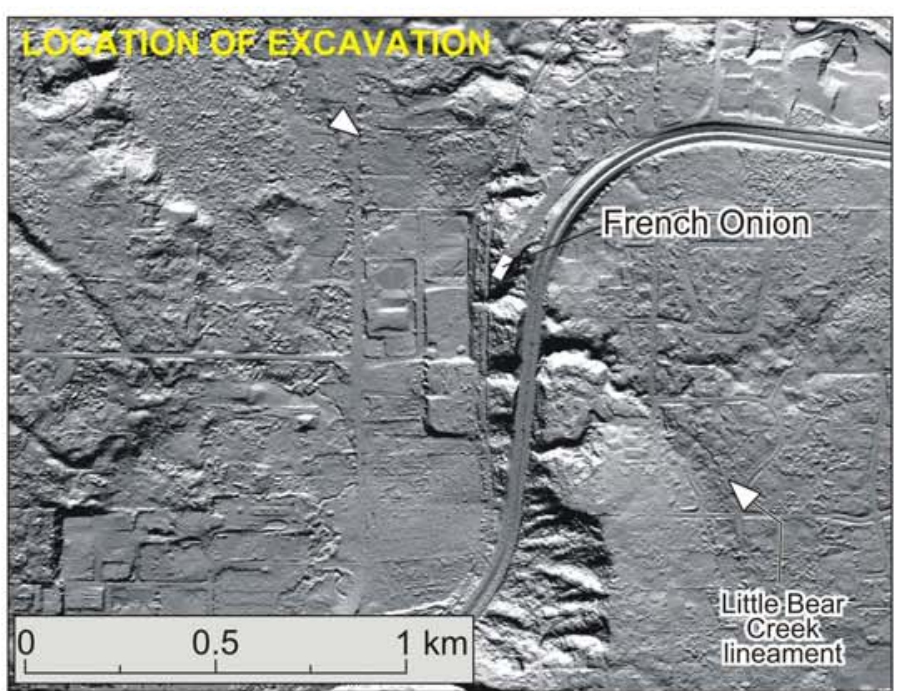

Qscl Brown to gray shattered, laminated claystone Quaternary glacial lake deposits

Figure 13 - Simplified excavation log of the French Onion trench (east wall). (Inset) Lidar image showing the excavation site. Log is flipped relative to actual mapped log to aid intercomparison of excavation logs in this report. 


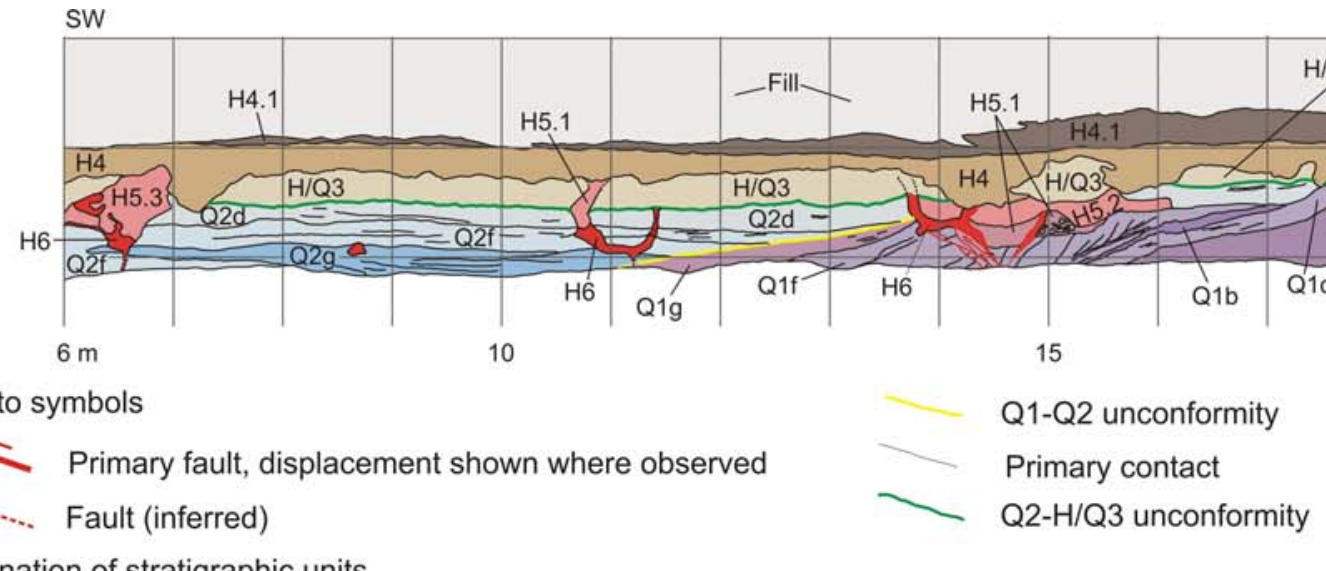

lanation of stratigraphic units

\begin{tabular}{|c|c|c|c|c|}
\hline $\mathrm{H} 6$ & $\begin{array}{l}\text { Olive gray sandy loam - } \\
\text { Holocene liquefaction deposit }\end{array}$ & \begin{tabular}{l} 
Oี \\
0 \\
\hdashline
\end{tabular} & Q2f & $\begin{array}{l}\text { Olive brown sandy loam - late } \\
\text { Quaternary recessional outwash }\end{array}$ \\
\hline H5. 3 & $\begin{array}{l}\text { Olive brown gravelly sandy clay loam } \\
\text { - Holocene liquefaction deposit }\end{array}$ & 总 & Q2d & $\begin{array}{l}\text { Olive brown pebbly sandy clay loam - } \\
\text { late Quaternary recessional outwash }\end{array}$ \\
\hline 5.2 & $\begin{array}{l}\text { Olive brown pebbly sandy loam - } \\
\text { Holocene liquefaction deposit }\end{array}$ & & Q2da & $\begin{array}{l}\text { Yellow brown sandy loam - late } \\
\text { Quaternary recessional outwash }\end{array}$ \\
\hline & $\begin{array}{l}\text { Olive brown sandy clay loam - } \\
\text { Holocene liquefaction deposit }\end{array}$ & & Q1g & $\begin{array}{l}\text { Olive brown sandy loam - late } \\
\text { Quaternary recessional outwash }\end{array}$ \\
\hline & $\begin{array}{l}\text { Dark brown organic-rich sandy loam - } \\
\text { disturbed Holocene soil }\end{array}$ & $\begin{array}{l}\bar{O} \\
\Phi \\
\end{array}$ & Q1f & $\begin{array}{l}\text { Olive brown silty clay loam - late } \\
\text { Quaternary recessional outwash deposit }\end{array}$ \\
\hline $\mathrm{H} 4$ & $\begin{array}{l}\text { Dark brown organic-rich sandy loam - } \\
\text { Holocene wetland soil }\end{array}$ & $\begin{array}{l}\vec{g} \\
\stackrel{\infty}{S}\end{array}$ & Q1d & $\begin{array}{l}\text { Olive brown loamy sand - late } \\
\text { Quaternary recessional outwash deposit }\end{array}$ \\
\hline $\mathrm{H} / \mathrm{Q} 3$ & $\begin{array}{l}\text { Olive brown gravelly sandy loam - } \\
\text { Holocene soil fluvial deposit }\end{array}$ & & Q1b & $\begin{array}{l}\text { Yellowish brown pebbly }(\sim 20 \%) \text { sand - late } \\
\text { Quaternary recessional outwash deposit }\end{array}$ \\
\hline Q2g & $\begin{array}{l}\text { Olive gray sandy clay to clay - late } \\
\text { Quaternary recessional outwash deposit }\end{array}$ & & Q1a & $\begin{array}{l}\text { Yellowish brown pebbly }(\sim 50 \%) \text { sand - late } \\
\text { Quaternary recessional outwash deposit }\end{array}$ \\
\hline
\end{tabular}

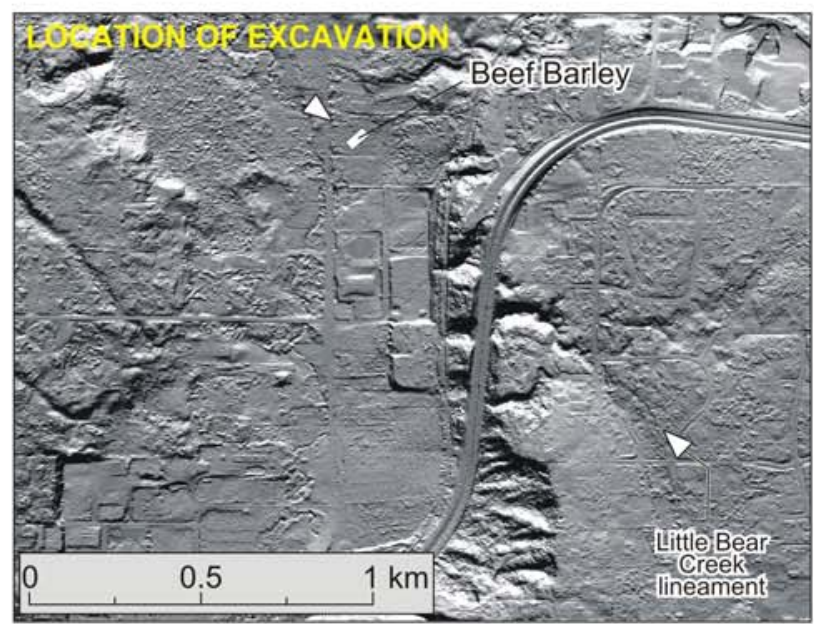

Figure 14-Simplified excavation log of the Beef Barley trench (west wall). (Inset) Lidar image showing the excavation site. 

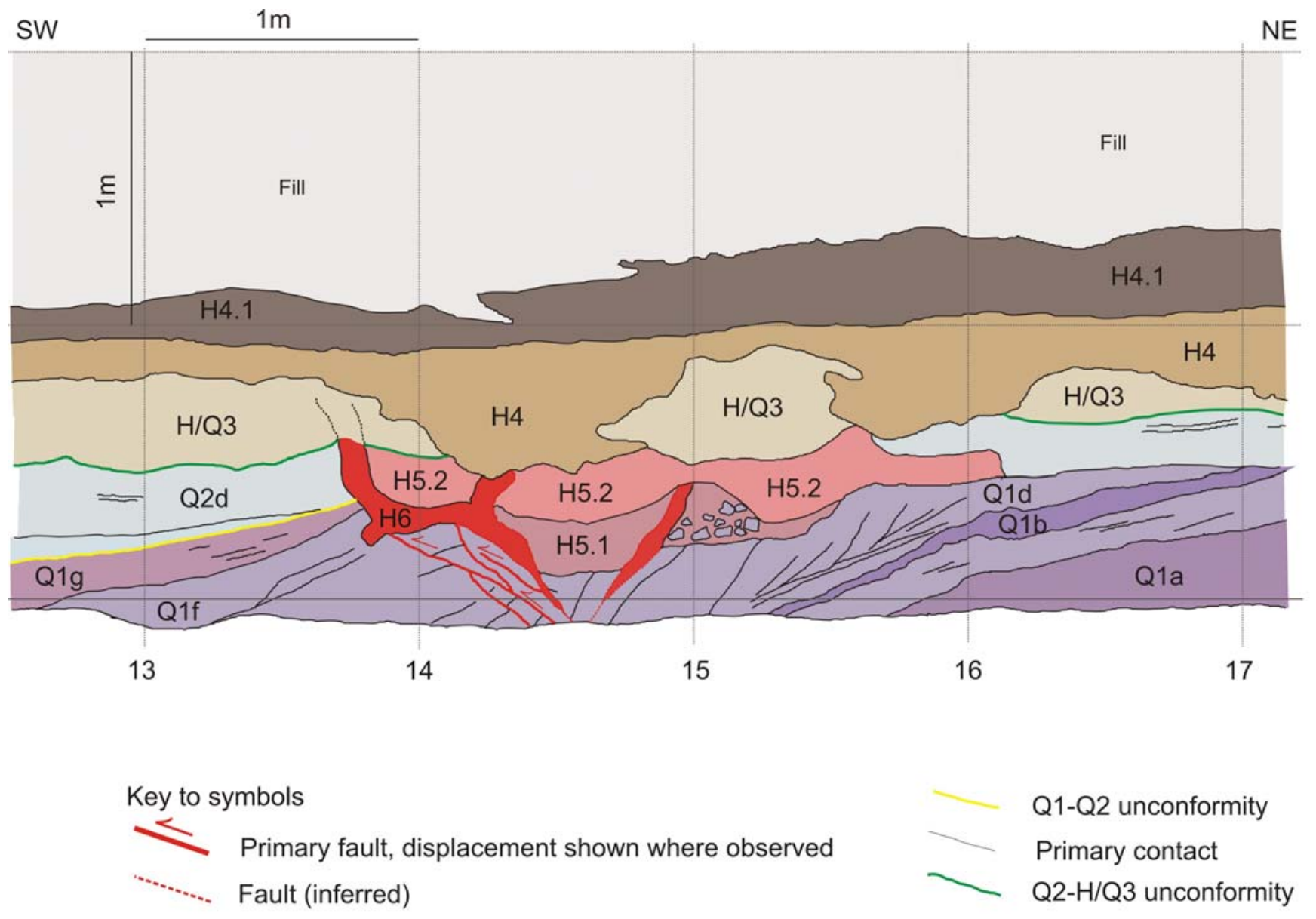

Figure 15 - Enlarged excavation diagram showing the area where several small reverse faults, the unconformities, and a large liquefaction feature were observed in the Beef Barley excavation. 


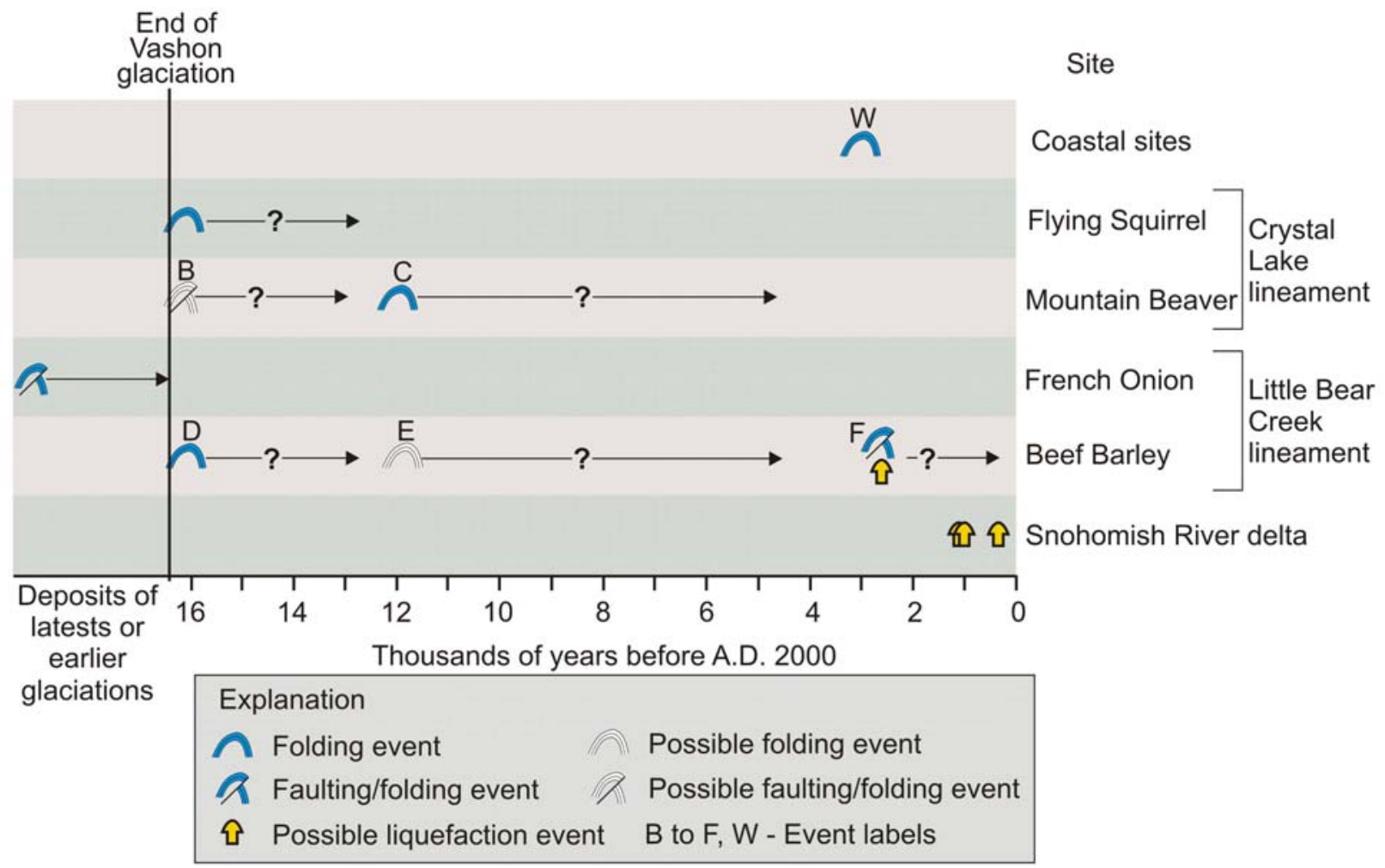

\section{LIST OF EVENTS}

\begin{tabular}{lll} 
Event & Age (yr B.P.) & Strand/Location \\
\hline Pre-Vashon faulting & pre-16,400 & Little Bear Creek \\
Normal faulting (B) & 16,400 to $\sim 12,000$ & Crystal Lake \\
Folding (D) & 16,400 to $\sim 12,000$ & Little Bear Creek \\
Folding (C) & post-11,670 to $\sim$ mid-Holocene & Crystal Lake \\
Folding/coastal uplift (W) & 3200 to 2800 & Whidbey Island \\
Faulting/folding (F) & post-2730 & Little Bear Creek \\
Liquefaction & 1150 to 1020 & Bourgeois and Johnson (2001) \\
Liquefaction & 1090 to 1010 & Bourgeois and Johnson (2001) \\
Liquefaction & 570 to 360 & Bourgeois and Johnson (2001)
\end{tabular}

Figure 16-Summary diagram of paleoseismological evidence along the SWIFZ. The text below the plot lists each the approximate age and strand of each event. Event labels are the same as those mentioned in the text. 


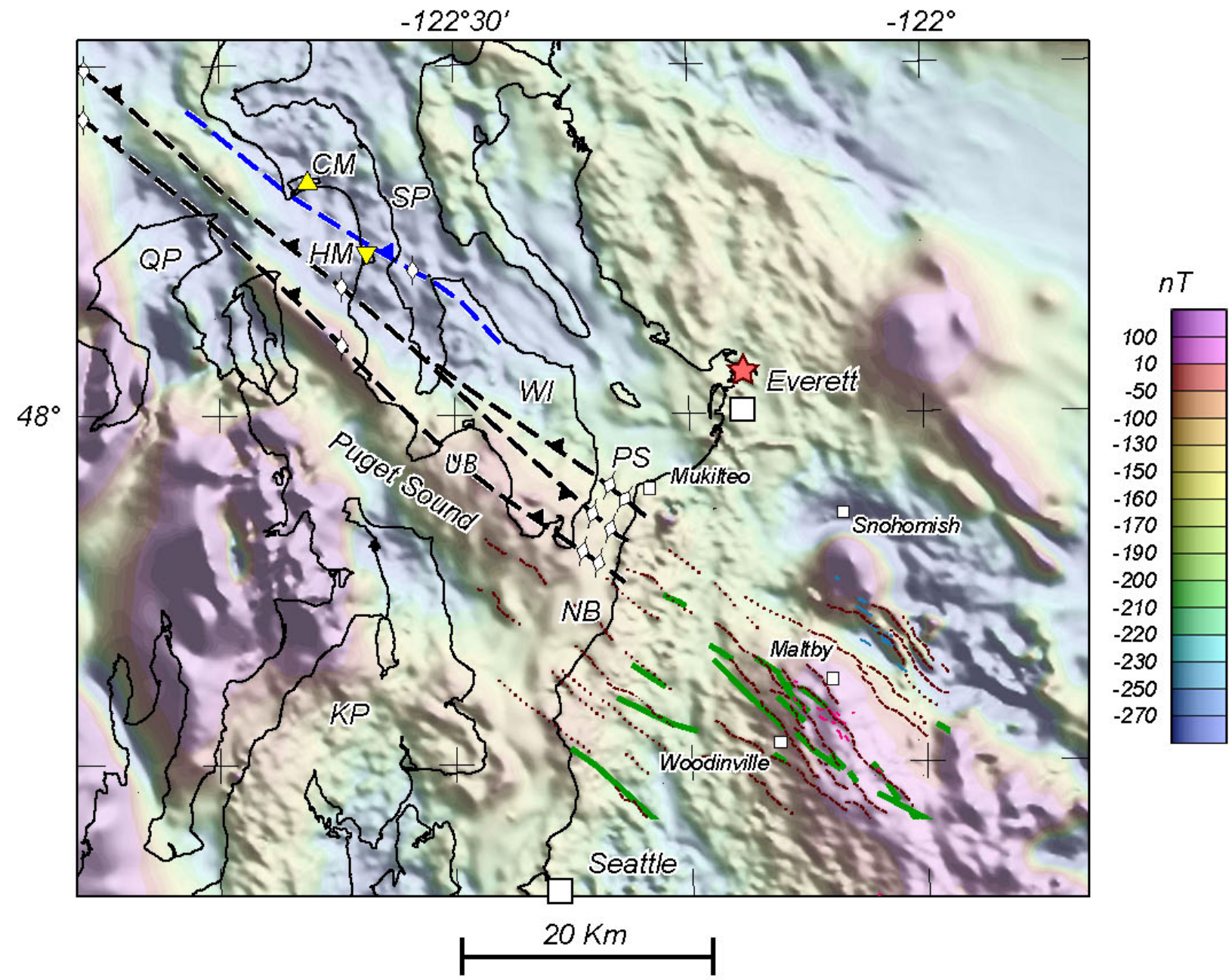

Figure 17-Map showing newly identified geologic features on the mainland with previously published evidence for the SWIFZ west of the mainland shore. Color-shaded relief map shows intensity of the magnetic field. Bold dashed lines west of the mainland shore are faults reported by Johnson and others (1996) and Kelsey and others (2004). White diamonds show locations of faulted Quaternary strata identified in marine seismic-reflection data (Johnson and others, 1996). Yellow triangles are sites of relative differences in Holocene sea-level changes (Kelsey and others, 2004). Red star is location of liquefaction evidence for multiple Holocene ground-shaking (Bourgeois and Johnson, 2001). Various dotted and dashed lines between Everett and Seattle are aeromagnetic, lidar, and airphoto lineaments. See Figures 2 and 6 for description of lines and labels. 